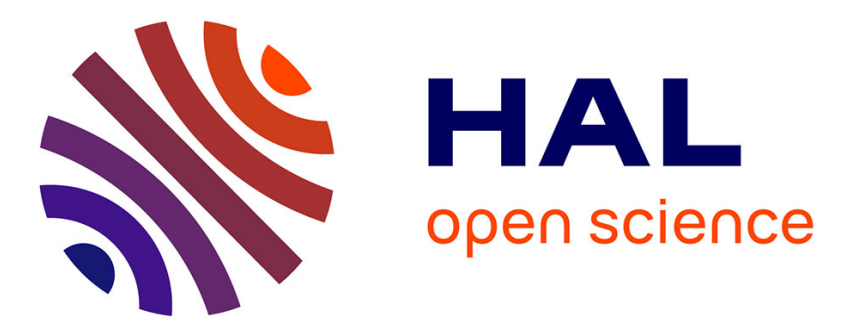

\title{
Arctic Snowfall from CloudSat Observations and Reanalyses
}

\author{
L. Edel, C. Claud, C. Genthon, C. Palerme, N. Wood, T. L'ecuyer, D.
} Bromwich

\section{- To cite this version:}

L. Edel, C. Claud, C. Genthon, C. Palerme, N. Wood, et al.. Arctic Snowfall from CloudSat Observations and Reanalyses. Journal of Climate, 2020, 33 (6), pp.2093-2109. 10.1175/JCLI-D-19-0105.1 . hal-02997782

\section{HAL Id: hal-02997782 \\ https://hal.science/hal-02997782}

Submitted on 3 Dec 2021

HAL is a multi-disciplinary open access archive for the deposit and dissemination of scientific research documents, whether they are published or not. The documents may come from teaching and research institutions in France or abroad, or from public or private research centers.
L'archive ouverte pluridisciplinaire HAL, est destinée au dépôt et à la diffusion de documents scientifiques de niveau recherche, publiés ou non, émanant des établissements d'enseignement et de recherche français ou étrangers, des laboratoires publics ou privés. 


\title{
Arctic Snowfall from CloudSat Observations and Reanalyses
}

\author{
L. Edel, C. Claud, and C. Genthon \\ LMD/IPSL, Ecole Polytechnique, IP Paris, ENS, PSL research University, Sorbonne University, CNRS, Palaiseau, France \\ C. PALERME
}

Development Centre for Weather Forecasting, Norwegian Meteorological Institute, Oslo, Norway

N. WOOD AND T. L'ECUYER

Department of Atmospheric and Oceanic Sciences, University of Wisconsin-Madison, Madison, Wisconsin

\section{BROMWICH}

Polar Meteorology Group, Byrd Polar, and Climate Research Center, The Ohio State University, Columbus, Ohio

(Manuscript received 7 February 2019, in final form 20 November 2019)

\begin{abstract}
While snowfall makes a major contribution to the hydrological cycle in the Arctic, state-of-the-art climatologies still significantly disagree. We present a satellite-based characterization of snowfall in the Arctic using CloudSat observations, and compare it with various other climatologies. First, we examine the frequency and phase of precipitation as well as the snowfall rates from CloudSat over 2007-10. Frequency of solid precipitation is higher than $70 \%$ over the Arctic Ocean and $95 \%$ over Greenland, while mixed precipitation occurs mainly over North Atlantic (50\%) and liquid precipitation over land south of $70^{\circ} \mathrm{N}(40 \%)$. Intense mean snowfall rates are located over Greenland, the Barents Sea, and the Alaska range $\left(>500 \mathrm{~mm} \mathrm{yr}^{-1}\right)$, and maxima are located over the southeast coast of Greenland (up to $2000 \mathrm{~mm} \mathrm{yr}^{-1}$ ). Then we compare snowfall rates with the European Centre for Medium-Range Weather Forecasts (ECMWF) interim reanalysis (ERAInterim, herein ERA-I) and Arctic System Reanalysis (ASR). Similar general geographical patterns are observed in all datasets, such as the high snowfall rates along the North Atlantic storm track. Yet, there are significant mean snowfall rate differences over the Arctic between $58^{\circ}$ and $82^{\circ} \mathrm{N}$ between ERA-I $\left(153 \mathrm{~mm} \mathrm{yr}^{-1}\right)$, ASR version $1\left(206 \mathrm{~mm} \mathrm{yr}^{-1}\right)$, ASR version $2\left(174 \mathrm{~mm} \mathrm{yr}^{-1}\right)$, and CloudSat $\left(183 \mathrm{~mm} \mathrm{yr}^{-1}\right)$. Snowfall rates and differences are larger over Greenland. Phase attribution is likely to be a significant source of snowfall rate differences, especially regarding ERA-I underestimation. In spite of its nadir-viewing limitations, CloudSat is an essential source of information to characterize snowfall in the Arctic.
\end{abstract}

\section{Introduction}

Over recent decades, the mean Arctic temperature has increased twice as fast as the global average. The hydrologic system plays a key role in global warming by its Arctic interactions between the atmosphere, ocean, ice, and snow. Indeed, Arctic precipitation depends on global processes, like the moisture transport from midlatitudes, and local processes, such as evaporation associated with sea ice retreat. Precipitation, and specifically

Corresponding author: L. Edel, leo.edel@lmd.polytechnique.fr snow, responds to environmental changes that may later impact Arctic climate. These interactions result in different feedbacks, leading to indistinct impacts that are difficult to disentangle. Several precipitation-related feedbacks are summarized next, as the literature on the subject is quite large (e.g., Francis et al. 2009; Serreze and Barry 2011).

Due to Arctic amplification, an increase of precipitation has been observed over the last decades on terrestrial areas in the Global Precipitation Climatology Centre (GPCC) dataset and general circulation models (GCMs) (Rawlins et al. 2010). In addition, temperature 
increases impact the phase of precipitation, leading to a more rainy Arctic (Bintanja and Selten 2014). A declining summer snowfall has also been reported over the last two decades, leading to a reduced area of snowcovered ice and a lower albedo, as well as a thinning of the sea ice and a delayed start of the sea ice growth (Screen and Simmonds 2012). However, a thin snowpack on sea ice would allow more heat loss to the atmosphere and potentially sea ice would grow back faster than with a thicker snowpack (Wang et al. 2019). Then, a later growth onset could be favorable to first-year ice growth due to less accumulated snow. Yet, smaller snowfall amounts may not be favorable for multiyear sea ice. Indeed, heavy autumn and winter snowfall have shown significant contribution to second-year ice thickness growth in the Atlantic sector of the Arctic (Merkouriadi et al. 2017), with the resulting thick snowpack preventing any bottom growth. Moreover, the change in sea ice cover leads to more exchanges between ocean and atmosphere, potentially resulting in a cloudier Arctic (Liu et al. 2012) and further impacts on precipitation. Hence, an improved characterization of precipitation is essential to reduce uncertainties on climate projections, in order to better understand and model the Arctic water cycle.

In the Arctic, the frequency and quantity of precipitation are associated with huge uncertainties due to few and sparse observations compared to lower latitudes. In addition, reliable measurements are challenging because of the difficult conditions in this region, and especially over oceanic areas and Greenland. According to the World Meteorological Organization (WMO) Solid Precipitation Intercomparison Experiment (SPICE) report (Nitu et al. 2018), snowfall is among the most complex parameters to measure at the ground, mainly due to blowing snow, undercatchment, and overcatchment, as well as freezing and evaporation inside the in situ instruments.

With these difficulties in mind, remote sensing appears to be one of the most relevant tools to investigate polar precipitation (e.g., Milani et al. 2018). The microwave frequencies are commonly used for their interactions with hydrometeors and their independence from sunlight, allowing observations throughout the year. Snowfall retrieval from passive microwave instruments is still at an early stage (e.g., Levizzani et al. 2011) and, to the authors' knowledge, very few algorithms have been developed for latitudes higher than $65^{\circ} \mathrm{N}$ (e.g., Surussavadee and Staelin 2009) and those that do exist contain large errors.

Since 2006, the CloudSat polar-orbiting satellite operates with the Cloud Profiling Radar (CPR) onboard. The specific characteristics of the CPR enable effective observations of light precipitation amounts (Mitrescu et al. 2010), typical of the Arctic. This is the first satellitebased radar instrument operating at latitudes as far north as $82^{\circ} \mathrm{N}$ and the first sensitive enough to reliably detect falling snow (Liu 2008). Thus, a quasi-global climatology of occurrence, phase, and quantity of precipitation can be obtained, based mostly on observations. Note that due to the challenges of obtaining reliable path-integrated attenuation over land and ice surfaces, CloudSat products estimate liquid phase precipitation only over open ocean, while solid phase precipitation is estimated over all surface types.

In this study, we focus on snowfall in the Arctic. In a first part, we describe the CloudSat climatology, and then evaluate the accuracy of reanalyses. We consider the European Centre for Medium-Range Weather Forecasts (ECMWF) interim reanalysis (ERA-Interim, hereinafter ERA-I), which has been shown to give good results over polar areas (Bromwich et al. 2011; Palerme et al. 2017) and two versions of the regional Arctic System Reanalysis (ASR). In the past, Behrangi et al. (2016) have compared precipitation from CloudSat with reanalyses and various observation-based products [e.g., the Global Precipitation Climatology Project (GPCP)] as well as with the Gravity Recovery and Climate Experiment (GRACE), a satellite that measures mass changes including snow accumulation on continental surfaces. Their main findings were that ERA-I agrees closely with CloudSat precipitation over high-latitude oceans. Yet, they did not specifically center their study on snowfall rates. Boisvert et al. (2018) compare precipitation rates from several reanalyses over the Arctic Ocean and its peripheral seas. Over 2000-16, they showed that magnitude, frequency, and phase of precipitation vary greatly; three global reanalyses (ERA-I, MERRA, and NCEP R2) followed closely by ASR provide realistic magnitude and a good temporal agreement with ice mass-balance buoys.

The structure of this paper is as follows: Section 2 describes the datasets and the production of the CloudSat climatology. Section 3 presents the results, while section 4 provides a discussion and conclusions.

\section{Data and methodology}

\section{a. CloudSat}

CloudSat, which launched in April 2006, is a polarorbiting satellite reaching up to $82^{\circ} \mathrm{N}$. The onboard $\mathrm{CPR}$ is a nadir-looking radar at $94 \mathrm{GHz}$ with a $1.7 \mathrm{~km} \times$ $1.4 \mathrm{~km}$ footprint, measuring 125 vertical bins each $240 \mathrm{~m}$ thick. The CPR sounds the atmosphere with a low detection threshold $(-28 \mathrm{dBZ})$, which is efficient to 
TABLE 1. Summary of CloudSat products used in this study.

\begin{tabular}{lll}
\hline \multicolumn{1}{c}{ Name } & \multicolumn{1}{c}{ Used variables } & \multicolumn{1}{c}{ Variable names } \\
\hline 2C-PRECIP-COLUMN & Occurrence, phase, uncertainty of precipitation & Precip_flag \\
2C-SNOW-PROFILE & Snowfall rates at the surface and uncertainties & snowfall_rate_sfc, snowfall_rate_sfc_uncert \\
\hline
\end{tabular}

observe light precipitation rates typical of the Arctic (Mitrescu et al. 2010). The along-track reflectivity profiles are used to create higher-level products. In this study, 2C-PRECIP-COLUMN (2C-PC) (Haynes et al. 2009) and 2C-SNOW-PROFILE (2C-SP) (Wood et al. 2014) version R05 are used. The first product gives precipitation and surface characteristics such as precipitation phase and occurrence, as well as surface type. The second product gives data related to snowfall quantification like the vertical distribution of snowfall rate and its uncertainty. Yet, the algorithm does not discriminate between convective and nonconvective snowfall. This partition can be computed using mainly 2C-SP and 2B-CLDCLASS products (e.g., Kulie et al. 2016; Kulie and Milani 2018). The cloud classification used in 2B-CLDCLASS requires CPR, Cloud-Aerosol Lidar and Infrared Pathfinder Satellite Observations (CALIPSO), and Moderate Resolution Imaging Spectroradiometer (MODIS) (Sassen and Wang 2008), adding further uncertainties due to horizontal resolution difference between instruments. Thereby, snowfall is defined as the sum of convective and nonconvective for the present investigation. The CloudSat precipitation products used in this study are summarized in Table 1.

We focus on the 4-yr period during which CloudSat was fully operational. After April 2011, a battery issue limited the measurements to daytime only. It is worth noting that December 2006 values are used to compute full seasonal means, whereas total means extend from January 2007 to December 2010. In agreement with Palerme et al. (2014), all CloudSat soundings north of $58^{\circ} \mathrm{N}$ are monthly averaged over $2007-10$ on a $1^{\circ}$ latitude $\times 2^{\circ}$ longitude grid, leading to a total number of overpasses per grid cell ranging from 200 below $70^{\circ} \mathrm{N}$ to 3000 close to $82^{\circ} \mathrm{N}$ (Fig. 1). From here, seasonal, annual, and total means can be obtained. Note that at this horizontal resolution CloudSat agrees well with groundbased radar measurements at three different stations in Antarctica (Souverijns et al. 2018).

For all measurements of one CPR orbit, only one phase and one probability of occurrence are retained for each grid cell overflown according to the following. CloudSat phase flag has four options: no precipitation, solid, liquid, or mixed. If there are several precipitation phases, precipitation is considered mixed. The CloudSat precipitation uncertainty flag is defined by near-surface reflectivity $R$ and has two options for snowfall: possible $(-5>R>-15 \mathrm{~dB})$ and certain $(R>-5 \mathrm{~dB})$. The higher the reflectivity, the more confident is the detection. This flag can be seen as an indication of precipitation intensity. Note that possible $(-7.5>R>-15 \mathrm{~dB})$ and probable $(0>R>-7.5 \mathrm{~dB})$ flags for rainfall events are both considered as possible events in our study. If at least one profile is detected as certain, then precipitation certain is retained. Otherwise, precipitation possible is kept. From the grid cell flags, frequencies of phase and uncertainty are calculated monthly, and then averaged seasonally and yearly. These approaches tend to increase the occurrences of certain and mixed-phase precipitation.

Due to ground clutter, the lower part of the reflectivity profile is contaminated and must be truncated. Thus, 2C-SP excludes information of the two lowest bins over open ocean (approximately $500 \mathrm{~m}$ ) and the four lowest bins over land and frozen surfaces including sea ice (approximately $1000 \mathrm{~m}$ ). The lowest bin in the corrected profile is defined as near-surface bin, whose snowfall rates are extrapolated to snowfall rates at the surface. A melting-layer model implemented in 2C-PC is used to

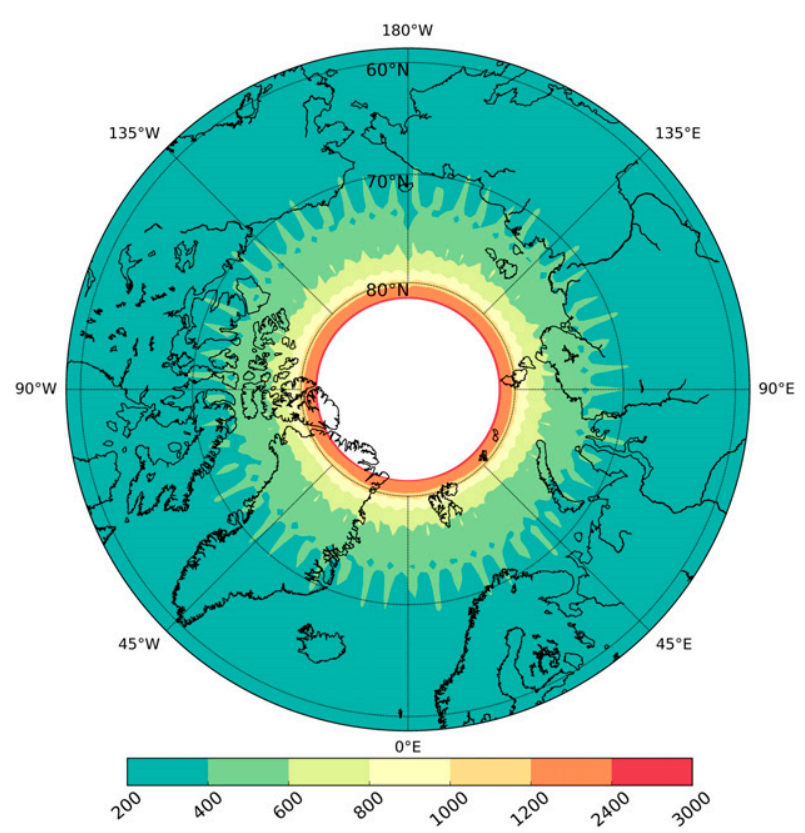

FIG. 1. Number of CloudSat overpasses per grid cell over 2007-10 at a $1^{\circ}$ latitude $\times 2^{\circ}$ longitude resolution. 
evaluate collocated ECMWF operational analysis temperature profiles to estimate the melted mass fraction of precipitation at the surface, and this is used to assess the phase of precipitation (Haynes et al. 2009). If the melted mass fraction is less than about 0.15 , the precipitation is classified as snow. If greater than about 0.15 , it is mixed phase or rain.

The 2C-SP algorithm is applied for all profiles with precipitation classified as snow and mixed-phase precipitation. The retrieval uses temperature-dependent a priori estimates of snow particle size distribution and microphysical and scattering properties to constrain the retrieval. The algorithm iteratively adjusts the slope parameter and intercept of an exponential size distribution to obtain a best estimate solution subject to the observed reflectivities and the a priori information. With this technique, the $Z-S$ relationship between radar reflectivity and snowfall rate is not fixed, but depends on the reflectivity profile and the a priori expectations. Retrieved uncertainties result from the uncertainties in the observed reflectivities, the approximate nature of the forward model, and its a priori assumptions. If the snowfall rate in the near-surface bin is much higher than in the bin immediately above, the observation should be taken with caution as this may be indicative of retrieval error. Wood and L'Ecuyer (2018) have identified three reasons that could explain a strong gradient between the near-surface bin and the bin immediately above. Over areas of complex terrain, the near-surface bin could be contaminated by ground clutter, which would produce a spuriously high snowfall rate (Milani et al. 2018; Palerme et al. 2019). If the near-surface bin is located in the melting layer, partial melting of snowflakes could also lead to a spuriously high snowfall rate because the forward model assumes dry snow properties. However, shallow precipitation could also produce a strong reflectivity gradient between the near-surface bin and the bin immediately above.

All profiles classified as snow ("certain" and "possible") are used in this study, except for erroneous profiles that have been excluded using the two flags further explained in this paragraph. In $2 \mathrm{C}-\mathrm{SP}$, the variable snow retrieval_status contains information about the issues encountered during the retrieval process. The flag value equals 3 when snowfall is detected at the surface and the retrieval performed without any difficulty. The condition where the snowfall rate in the near-surface bin is much larger than in the bin immediately above is reported by setting a bit in the value of snow_retrieval_ status, generally giving a flag value $=11$. Further, very deep or very intense snowfall will cause large forward model uncertainties related to parameterizations for multiple scattering and attenuation corrections, and these conditions also reduce confidence. Profiles reported as such and profiles whose retrieval also produced large chi-square values (generally giving a flag value $\geq 15$ ) have been excluded from the climatology, following Palerme et al. (2019). The second flag, named snowfall_rate_sfc_confidence, estimates the confidence in the retrieval based on its uncertainties, the phase of precipitation, the type of surface, and the snow_retrieval_status flag. In this study, all profiles reported with very low confidence (flag $\leq 1$ ) have been removed from the climatology. This value is set for partially melted snow (melting ratio $>0.15$ ) and may be obtained by dry snowfall profiles depending on the parameters enunciated above. Due to the retrieval algorithm context, the uncertainties are partially systematic and random. By averaging years of snowfall rates, the random component of the uncertainties is significantly reduced, but it remains difficult to assess the bias caused by systematic errors.

A number of studies have evaluated the snowfall retrievals from the 2C-SP product using ground-based radar networks as reference over the United States (Cao et al. 2014; Chen et al. 2016), Sweden (Norin et al. 2015), and the Antarctic ice sheet (Souverijns et al. 2018; Lemonnier et al. 2019). They indicate that the 2C-SP algorithm performs well for light precipitation, but may underestimate snowfall rates for moderate and heavy snowfall (Cao et al. 2014; Norin et al. 2015; Chen et al. 2016). Over Antarctica, the CloudSat snowfall climatology provides very good results compared to radar total snowfall amount records at three stations, showing the skill of CloudSat for the estimation of the surface snowfall climatology over the ice sheet (Souverijns et al. 2018). In addition, the phase discrimination of the 2C-SP algorithm is in fair agreement with ground-based radar observations (Chen et al. 2016).

\section{b. Reanalyses}

Monthly mean solid precipitation at the surface from ERA-I and ASR are used for comparison (Table 2). Various observations, coming from ground stations, radiosondes, and satellites, are assimilated, yet CloudSat data and precipitation measurements are not used to produce these reanalyses.

ERA-I has 60 vertical levels with a horizontal resolution of $\sim 80 \mathrm{~km}$ and generates analyses and predicted atmospheric fields every $6 \mathrm{~h}$ (Dee et al. 2011). The cloud microphysics scheme represents the physical processes of generation and destruction of cloud and precipitation in the model. It is based on Tiedtke (1993), which divides the total cloud condensate into diagnostic liquid and solid precipitation based on temperature. ASR (Bromwich et al. 2016) is a recent regional reanalysis 
TABLE 2. Summary of reanalyses used in this study.

\begin{tabular}{llccc}
\hline \hline Name & \multicolumn{1}{c}{ Type } & Duration & Spatial resolution & Reference \\
\hline ERA-I & Global reanalysis & $1979-$ present & $80 \mathrm{~km}$ & Dee et al. (2011) \\
ASR v1 & Regional reanalysis & $2000-12$ & $30 \mathrm{~km}$ & Bromwich et al. (2016) \\
ASR v2 & Regional reanalysis & $2000-12$ & $15 \mathrm{~km}$ & Bromwich et al. (2018) \\
\hline
\end{tabular}

produced on 71 vertical levels with a 3-h output. ASR uses the polar version of the Weather Research and Forecasting (WRF) Model with lateral boundary conditions from ERA-I, whose data are also used for spectral nudging above $100 \mathrm{hPa}$. The physics configuration for clouds and precipitation is based on the Goddard microphysics scheme (Tao and Simpson 1993), enhanced by many complementary parameterizations such as the Kain-Frisch cumulus parameterization (Kain and Fritsch 1990; Kain 2004). Rain, snowfall, and ice are prognostically determined based on the temperature regime (Tao 2003; Tao et al. 2014). This analysis includes solid convective precipitation for ASR (both versions) that is estimated by multiplying the "cumulus precipitation" by the fraction of frozen precipitation that is calculated by WRF for the nonconvective solid precipitation; that is, it is assumed that the same fraction of frozen precipitation applies to both nonconvective and convective precipitation.

The first (Bromwich et al. 2012, 2016) and second (NCAR 2017; Bromwich et al. 2018) versions of ASR have respectively 30 - and $15-\mathrm{km}$ horizontal resolution over the Arctic and are hereafter referred to as ASRv1 and ASRv2. ASRv2 total precipitation is in better agreement than ASRv1 during the warmer months of May-August and is drier than ASRv1 during the colder months of November-February, when compared to polar stations (Bromwich et al. 2018).

ERA-I is a global reanalysis whereas ASR is regional, including more detailed processes of the hydrologic cycle. ASR uses fractional sea ice within each grid cell, and includes additional sea ice characteristics. In particular, ASR takes into account sea ice concentration, thickness, albedo, and snow cover on sea ice, which vary seasonally whereas in ERA-I these characteristics are prescribed, follow a fixed climatology, or are not taken into account.

For consistency with observations, reanalyses have been bilinearly interpolated to the $1^{\circ}$ latitude $\times 2^{\circ}$ longitude CloudSat grid and snowfall is considered as the sum of convective and nonconvective solid precipitation.

\section{Results}

\section{a. CloudSat snowfall climatology}

The mean frequencies of solid, mixed, and liquid phase are plotted in Fig. 2. As expected, frequency of solid precipitation is higher than $\sim 70 \%$ over the central Arctic Ocean and $\sim 95 \%$ over Greenland, except for the coastal areas. Mixed-phase precipitation is found mainly in the North Atlantic and southern Alaska, with a mean frequency of around $50 \%$. Liquid phase precipitation

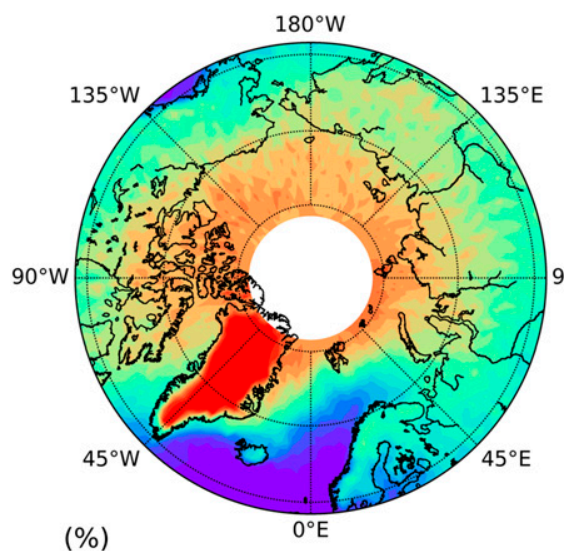

(\%)

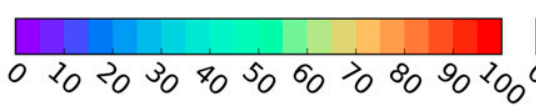

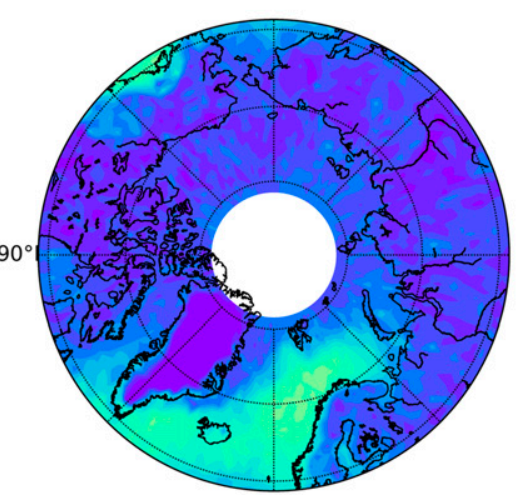

(\%)

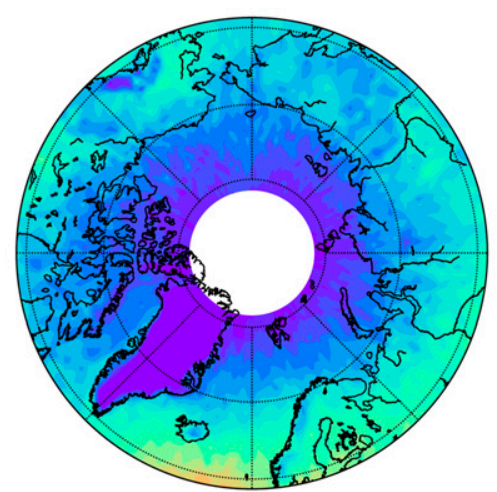

(\%)

FIG. 2. Frequency (\%) of profiles detected as (left) solid, (center) mixed, and (right) liquid phase compared to all precipitating profiles over 2007-10. 

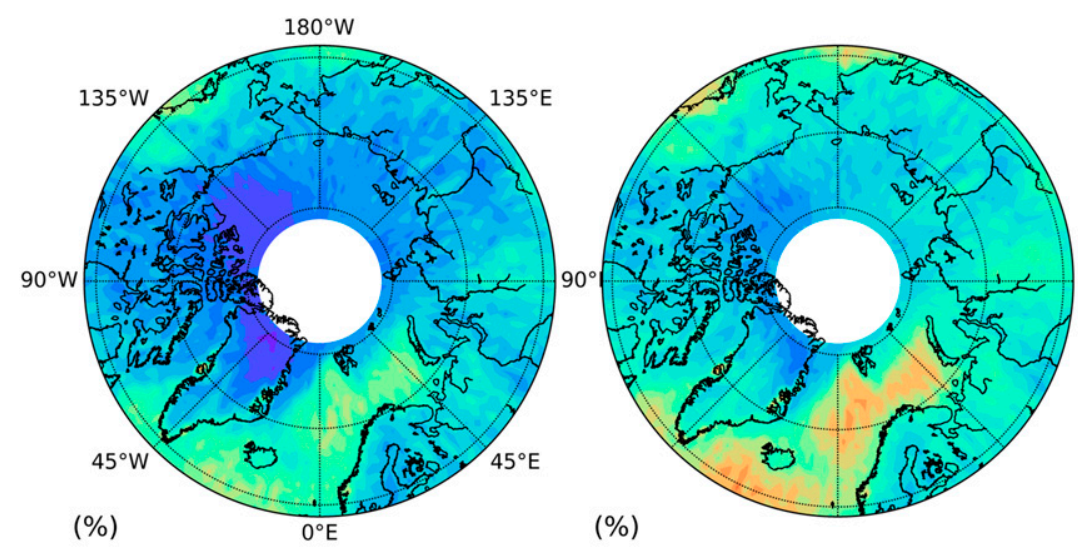

$(\%)$

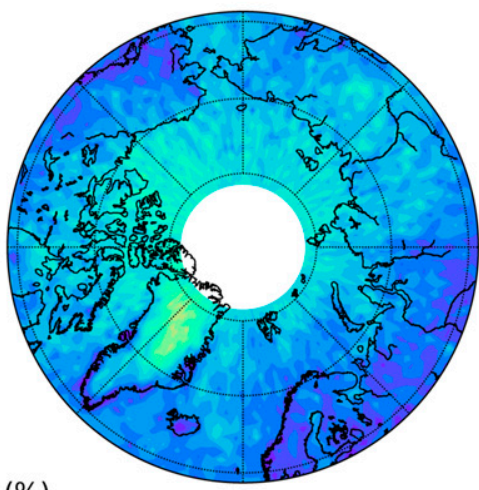

$(\%)$

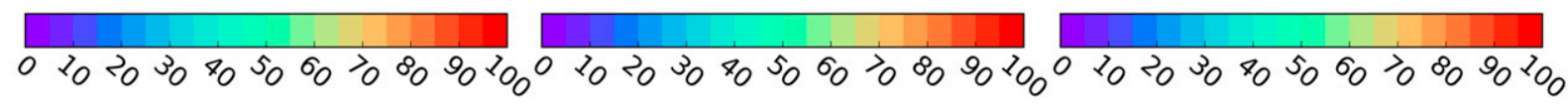

FIG. 3. Frequency of precipitating profiles (\%) detected as (left) certain and (center) certain or possible, and (right) the fraction (\%) of precipitating pixels detected as possible compared to all profiles over 2007-10.

frequency is about $40 \%$ over continents south of $70^{\circ} \mathrm{N}$ excluding mountainous areas (i.e., the Alaska range, Greenland, and the Canadian Archipelago). Interestingly, there is a significant amount $(\sim 5 \%-15 \%)$ of mixed and liquid precipitation in the Arctic Ocean peripheral seas.

Frequencies of precipitating profiles evaluated as certain, and as either certain or possible, and the fraction of possible precipitating profiles compared to all profiles are plotted in Fig. 3. Profiles detected as nonprecipitating by CloudSat are included in these estimations. Higher frequencies of certain precipitation (hereinafter, "certain" and "possible" precipitation, used without quotation marks, refer to the definitions in section 2) are observed in mountainous areas like the coasts of Greenland, the Norway range, and Baffin Island (west of Greenland) as well as the Alaska range. The high frequency (around $60 \%$ ) of certain precipitation above open ocean in the North Atlantic is likely due to the storm track along this area. Indeed snowfall and rainfall events may be more intense there than in drier parts of the Arctic, and thus higher reflectivities would be observed. Over the central Arctic, precipitation frequency ranges from $5 \%$ to $20 \%$ when profiles evaluated as certain are taken into account and from $10 \%$ to $40 \%$ when profiles detected as possible are included. The ratio around $50 \%$ specifies an equivalent number of profiles detected as certain and possible, while most detected profiles are sorted as possible over central Greenland. Despite the low detection threshold of the $\mathrm{CPR}$, the detection is less certain for weak snowfall rates and small frozen hydrometeors encountered in cold and dry areas. Although a considerable fraction of profiles are detected as possible, which may contain a small proportion of false detection, it remains extremely important to take into account the supposedly weak snowfall rates over the central Arctic and the Canadian Archipelago as well as to the east of Siberia.

Figure 4 (left) presents the climatology of snowfall rates at the surface. The mean surface snowfall rates are particularly high on the Greenland and Barents Seas $\left(\sim 600 \mathrm{~mm} \mathrm{yr}^{-1}\right)$ and the Alaska range $\left(\sim 1000 \mathrm{~mm} \mathrm{yr}^{-1}\right)$ and extremely high over the southeastern coast of Greenland, reaching $2000 \mathrm{~mm} \mathrm{yr}^{-1}$ (up to $4000 \mathrm{~mm} \mathrm{yr}^{-1}$ seasonally). Interestingly, when examining with Fig. 2, areas with high snowfall frequencies do not always match areas of high snowfall rates (e.g., in the Beaufort and Baffin Seas or Siberia). The relative uncertainty (Fig. 4, right), expressed as the ratio between the mean single surface snowfall rate uncertainty and the surface snowfall rate, ranges from 1.5 to 2.5 . It peaks to around 2.5 over the east coast of Greenland, while it remains high $(\sim 2)$ in the North Atlantic. These high relative uncertainties may be linked to complex topography and high frequency of mixed phase precipitation, as seen in Fig. 2. It should be noted that, because the uncertainty in the climatology is a mean of profiles, the standard error of the mean decreases as the number of averaged samples increases. As nonsnowfall profiles (with null uncertainty) are included, the uncertainty is further decreased.

Figure 5 displays snowfall rate differences between a climatology including all profiles without any discrimination on confidence flag and the retained climatology including only profiles with a confidence superior to 1 (described as "very low confidence" in the CloudSat product). As expected, taking into account all confidence profiles increases snowfall rates. The mean snowfall rate over the whole Arctic is $211 \mathrm{~mm} \mathrm{yr}^{-1}$ when including all 

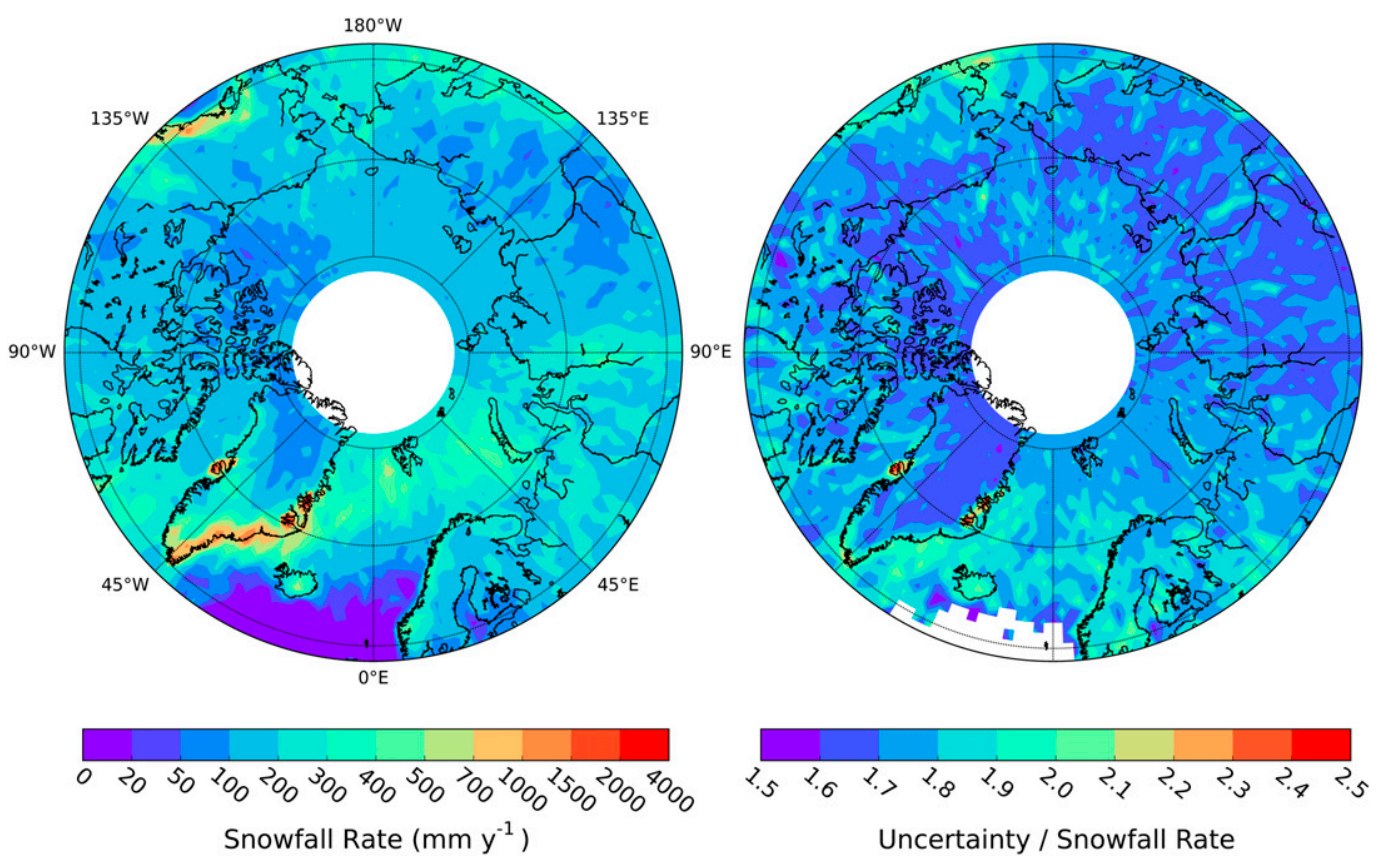

Uncertainty / Snowfall Rate

FIG. 4. (left) Mean surface snowfall rate and (right) fractional uncertainty over 2007-10.

profiles, while it is $183 \mathrm{~mm} \mathrm{yr}^{-1}$ for the retained climatology. Differences are important (up to $200 \mathrm{~mm} \mathrm{yr}^{-1}$ ) over the south of Greenland and the Norwegian and the Barents Seas, which are often ice-free areas, and remain low over continents and the Arctic Ocean (around $20 \mathrm{~mm} \mathrm{yr}^{-1}$ ). As the differences are higher where mixed precipitation tends to occur (Fig. 2, middle), it seems likely that most of the profiles removed correspond to partially melted snowfall, as described in section 2a. As reanalyses only consider dry snowfall, the profiles detected as mixed-phase precipitation by CloudSat have been excluded for the comparison.

\section{b. Comparison with reanalyses}

Figure 6 presents the seasonal surface snowfall rates retrieved from CloudSat and for ERA-I, ARSv1, and ASRv2 reanalyses. There is a good qualitative agreement between all datasets. Yet, multiple local differences are observed between patterns for both global and regional reanalyses. In winter, this is evident over the Ural Mountains (western Russia), where high snowfall rates are depicted by ASR $\left(\sim 700 \mathrm{~mm} \mathrm{yr}^{-1}\right)$ while it is less clear in ERA-I $\left(\sim 400 \mathrm{~mm} \mathrm{yr}^{-1}\right)$. Above the Norwegian range, ASR and CloudSat snowfall rates are close (up to $\sim 1000 \mathrm{~mm} \mathrm{yr}^{-1}$ ), while ERA-I shows weaker snowfall rates (up to $\sim 700 \mathrm{~mm} \mathrm{yr}^{-1}$ ); over Iceland, ASR shows higher snowfall rates $\left(\sim 2000 \mathrm{~mm} \mathrm{yr}^{-1}\right)$ than CloudSat $\left(\sim 700 \mathrm{~mm} \mathrm{yr}^{-1}\right)$ whereas ERA-I shows lower snowfall rates $\left(\sim 500 \mathrm{~mm} \mathrm{yr}^{-1}\right)$. This behavior can be observed for each season.
When comparing the datasets quantitatively, the differences vary both spatially and temporally. Indeed, percentage differences between each reanalysis and CloudSat are up to $350 \%$, as shown in Fig. 7. Differences between reanalyses and CloudSat occur over the whole Arctic, with different behaviors depending on the

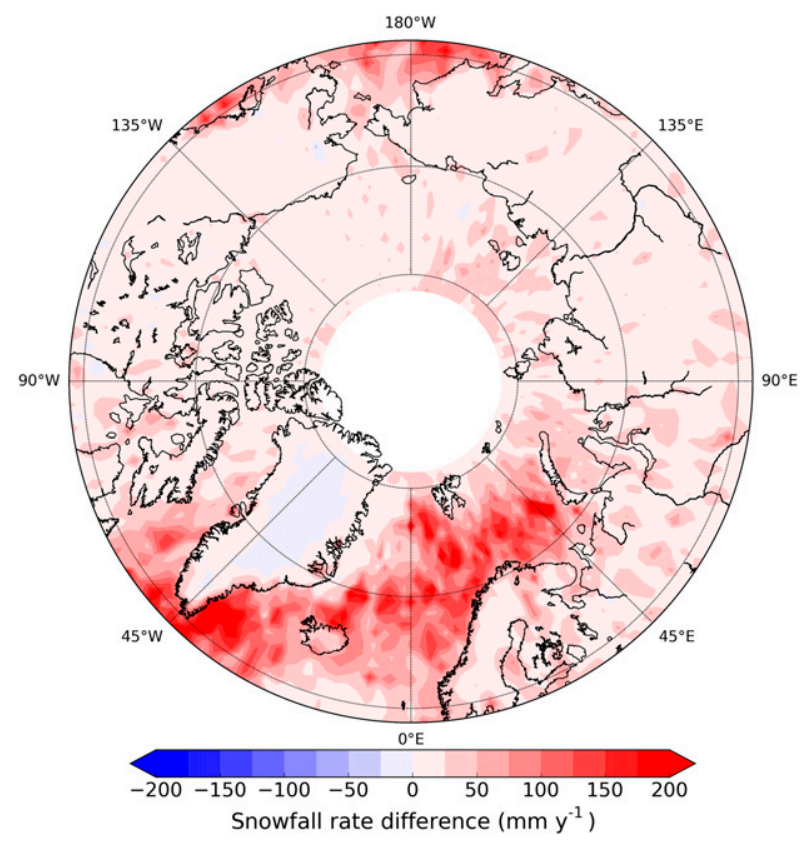

FIG. 5. Mean surface snowfall rate differences $\left(\mathrm{mm} \mathrm{yr}^{-1}\right)$ between CloudSat climatology including profiles described as "very low confidence" and excluding those profiles, over 2007-10. 


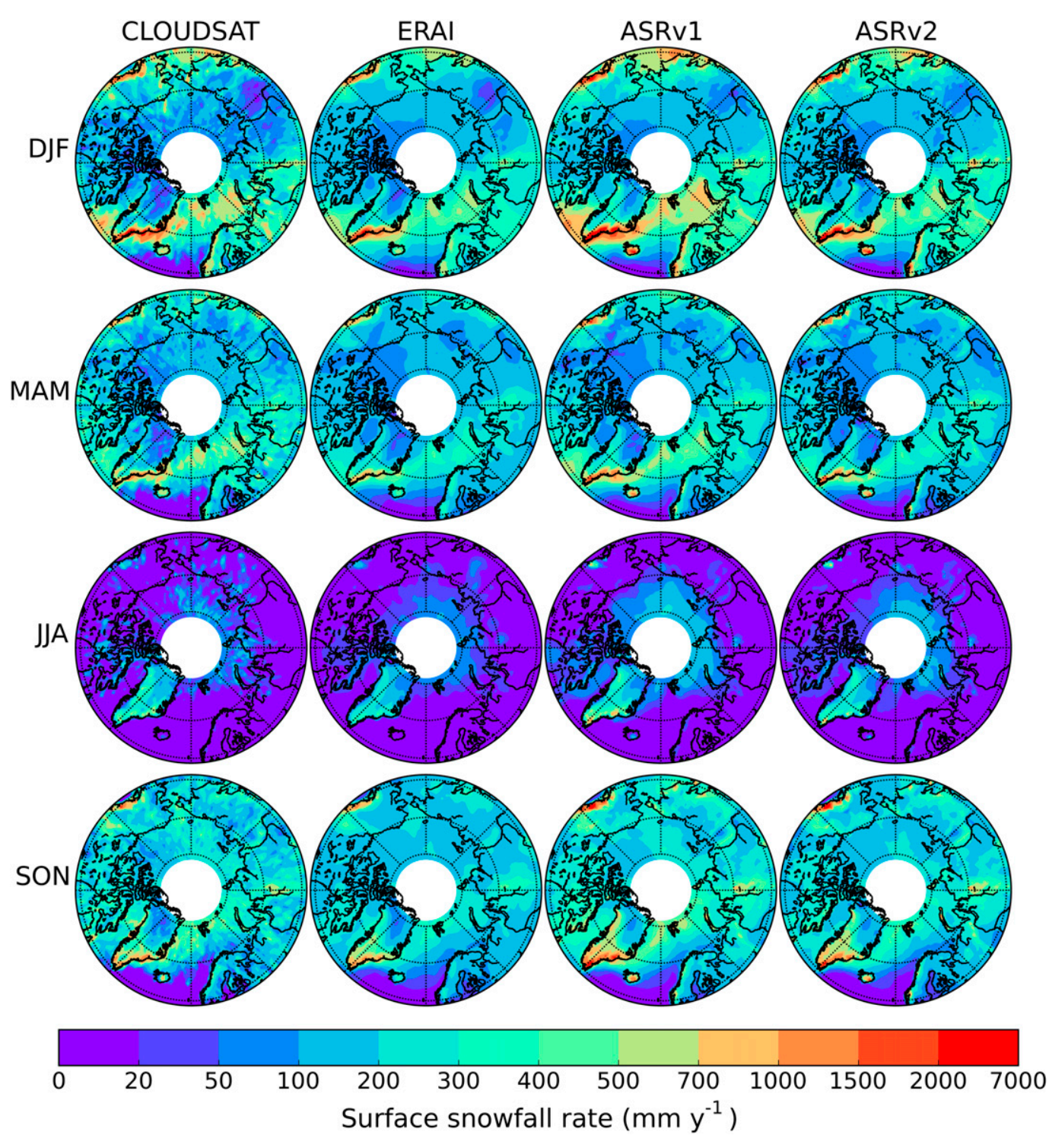

FIG. 6. Seasonal mean of surface snowfall rate over 2007-10 for winter (DJF), spring (MAM), summer (JJA), and autumn (SON) for (left to right) CloudSat, ERA-I, ASRv1, and ASRv2.

reanalysis and the season. In winter, large positive differences between reanalyses compared to CloudSat are located over Siberia, the Canadian Archipelago, and Greenland. Over these areas, ASR (both versions) snowfall rates are more intense than ERA-I compared to CloudSat. Over the North Atlantic, ERA-I and ASRv2 present a weaker snowfall rate $(-75 \%)$ whereas ASRv1 shows slightly more snowfall $(+50 \%)$, when compared to CloudSat. In summer, ASR overestimates snowfall rates over the whole Arctic Ocean compared to CloudSat; this overestimation is not so uniform in ERA-I with alternatively, areas of positive and negative differences. During this season, weak snowfall rates are measured, so a small difference tends to increase largely the percentage difference. Figure 8 shows surface snowfall rate differences between reanalyses and CloudSat in millimeters per year. During summer, biases are of the same order of magnitude as the snowfall rates (up to 60 and $120 \mathrm{~mm} \mathrm{yr}^{-1}$ for ERA-I and ASR, respectively) over the Arctic Ocean and extremely high (up to 100 and $400 \mathrm{~mm} \mathrm{yr}^{-1}$ ) and low (down to -200 and $-300 \mathrm{~mm} \mathrm{yr}^{-1}$ for ERA-I and ASR, respectively) over southern Greenland. The distribution of the differences can be observed in Fig. 9. The 25th and 75th percentile amplitudes $\left(\sim 100 \mathrm{~mm} \mathrm{yr}^{-1}\right)$ are almost similar between all datasets and for all seasons, except for summer $\left(\leq 40 \mathrm{~mm} \mathrm{yr}^{-1}\right)$. However, percentile differences vary greatly within a dataset for each season (i.e., $290 /-180 \mathrm{~mm} \mathrm{yr}^{-1}$ in 

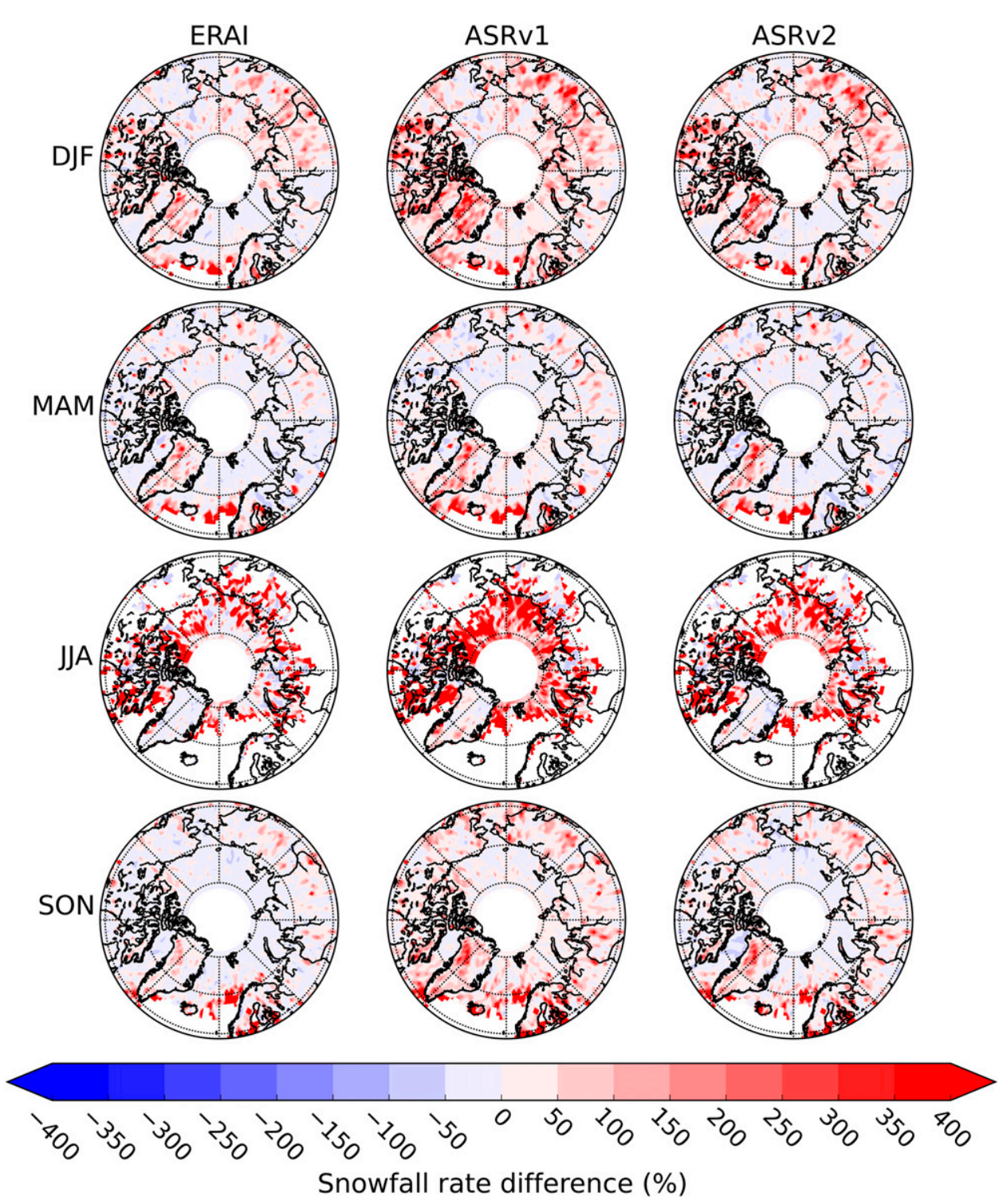

FIG. 7. Seasonal percentage difference of surface snowfall rate between (left) ERA-I, (center) ASRv1, and (right) ASRv2 and CloudSat for winter (DJF), spring (MAM), summer (JJA), and autumn (SON) over 2007-10.

winter, $100 /-50 \mathrm{~mm} \mathrm{yr}^{-1}$ in summer for ASRv1) and between datasets $\left(25 /-25 \mathrm{~mm} \mathrm{yr}^{-1}\right.$ in summer for ASRv2). ASRv2 shows lower seasonal snowfall rate differences with CloudSat throughout the year $\left(\leq 10 \mathrm{~mm} \mathrm{yr}^{-1}\right)$ except in spring, during which ASRv1 is in better agreement $\left(\leq 10 \mathrm{~mm} \mathrm{yr}^{-1}\right)$.

Differences of snowfall rates are further investigated in Fig. 10, which compares the seasonal snowfall rates between all reanalyses and CloudSat, with a distinction between oceanic and continental surfaces. Scatterplots show values in the range $0-2000 \mathrm{~mm} \mathrm{yr}^{-1}$ to ensure visibility of weak and moderate snowfall rates. In general, ASR (both versions) is in better agreement with
CloudSat than ERA-I. Indeed, ERA-I tends to significantly underestimate the high snowfall rates compared to CloudSat (over all surfaces) and tends to overestimate weak snowfall rates over open water. In spite of important mean biases of $-41 \mathrm{~mm} \mathrm{yr}^{-1}$ over land and $-31 \mathrm{~mm} \mathrm{yr}^{-1}$ over continents (Table 3 ), correlation coefficients between ERA-I and CloudSat are 0.77 and 0.89 , respectively. ASRv2 shows a similar underestimation over ocean compared to CloudSat but weaker than ERA-I, as confirmed by smaller bias values $\left(-20 \mathrm{~mm} \mathrm{yr}^{-1}\right)$. ASRv1 shows the closest linear regression slopes to the bisectrix (Fig. 10) over all surfaces and for each season, but shows a larger spread than ERA-I. 

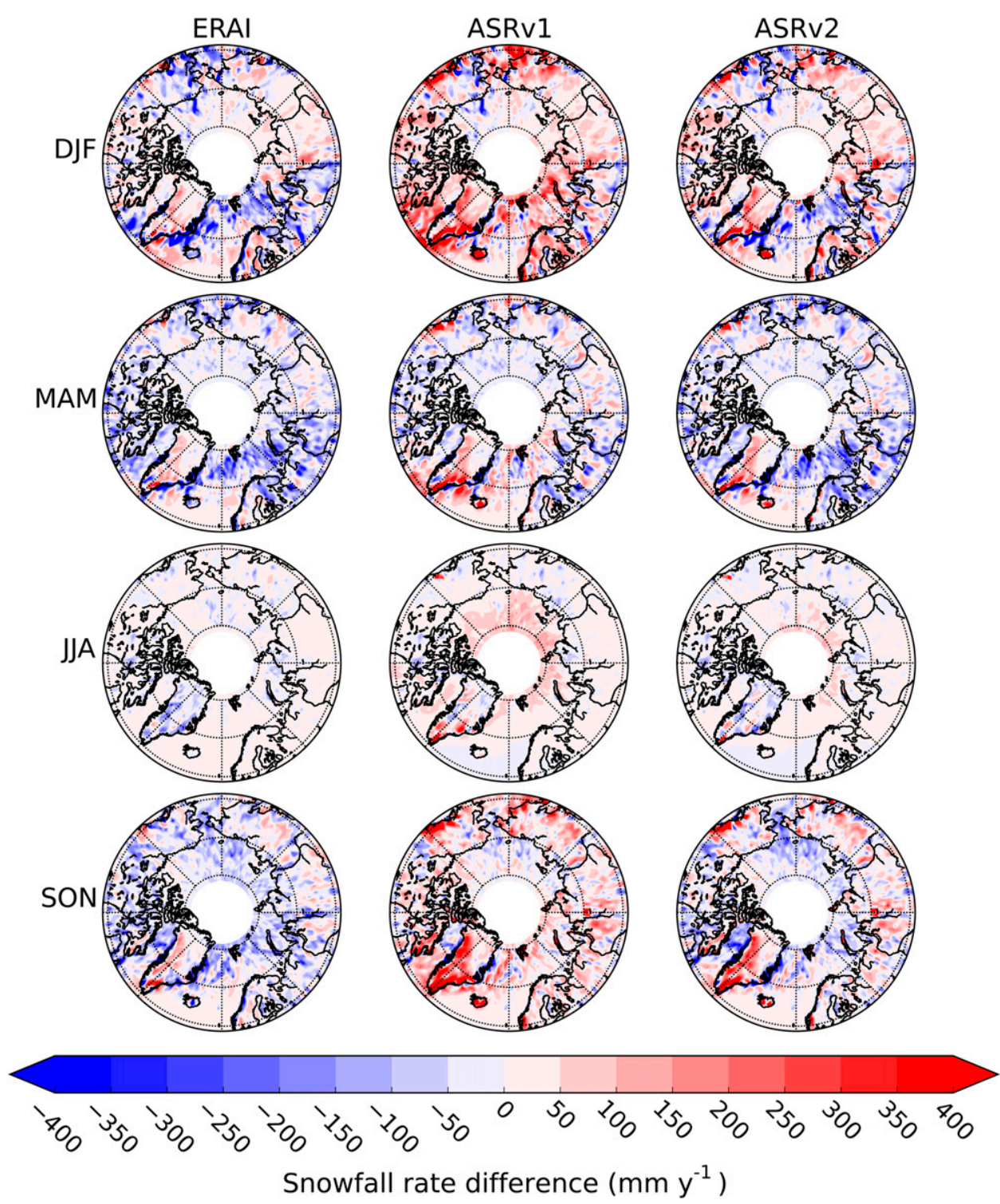

FIG. 8. Seasonal differences $\left(\mathrm{mm} \mathrm{yr}^{-1}\right)$ of surface snowfall rates between (left) ERA-I, (center) ASRv1, and (right) ASRv2 and CloudSat for winter (DJF), spring (MAM), summer (JJA), and autumn (SON) over 2007-10.

When comparing ASR (both versions) to CloudSat, the highest correlation coefficients $(0.88)$ are found over ocean, while the lowest biases are located over land (12 and $-12 \mathrm{~mm} \mathrm{yr}^{-1}$ for ASRv1 and ASRv2, respectively), revealing a closer agreement of snowfall rates over continental surfaces. Seasonal biases (Table 3) tend to be higher in colder months, during which heavier snowfall occurs. ASR (both versions) seasonal snowfall rates show lower biases with CloudSat than ERA-I, except for winter over all surfaces for ASRv1 (54 and $51 \mathrm{~mm} \mathrm{yr}^{-1}$ ) and summer over ocean for ASRv1 $\left(39 \mathrm{~mm} \mathrm{yr}^{-1}\right)$ and ASRv2 $\left(15 \mathrm{~mm} \mathrm{yr}^{-1}\right)$. The distinct patterns of snowfall distribution between the reanalyses are partially related to differences between the ERA-I and ASR precipitation schemes (Dutra et al. 2011), including how precipitation phase is determined.

Considering the 4320 grid cells of each map in Fig. 6, the snowfall rate distribution is shown for each season (Fig. 11). ERA-I tends to show a higher occurrence of moderate snowfall rates and a lower occurrence of weak and strong snowfall rates compared to CloudSat. The intensity of snowfall events depends on the season and the resulting weak, moderate, and intense categories in the following have been selected subjectively. The moderate snowfall rates are considered as 100-300 (DJF), 50-200 (MAM), 20-50 (JJA), and 100-200 $\mathrm{mm} \mathrm{yr}^{-1}$ (SON) while 


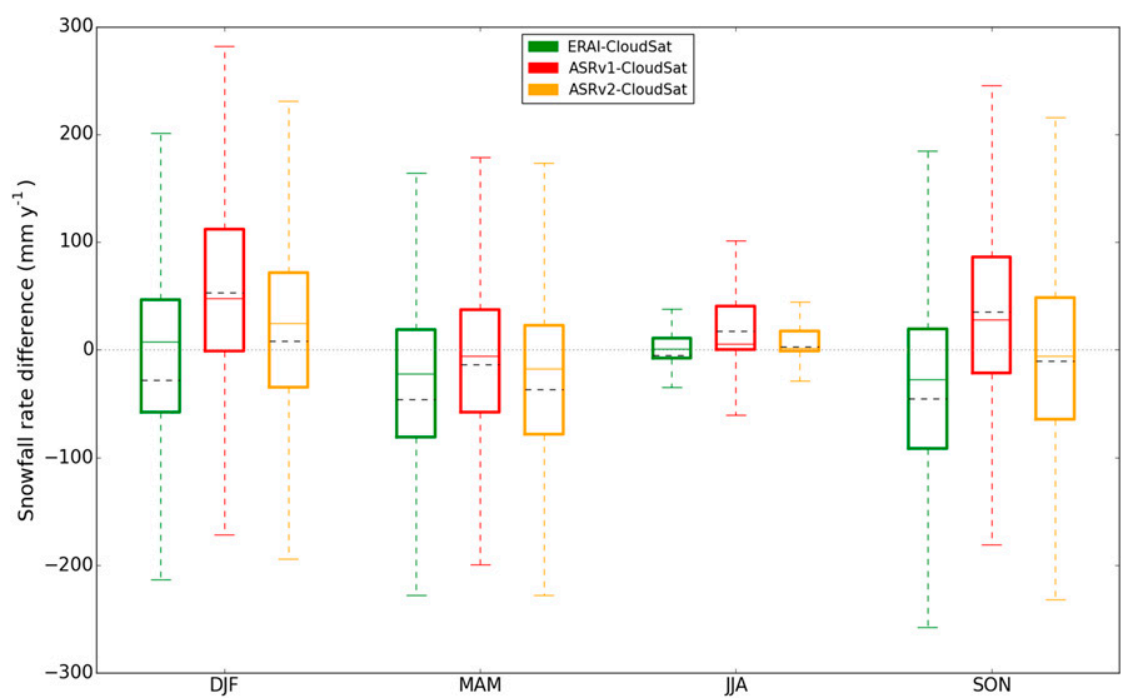

FIG. 9. Boxplot of seasonal differences $\left(\mathrm{mm} \mathrm{yr}^{-1}\right)$ of surface snowfall rates between reanalyses and CloudSat for each season over 2007-10. The horizontal full line within the box represented the median while the dotted line represents the mean. The bottom and top box bounds show the 25 th and 75 th percentiles, respectively, while bottom and top whiskers bounds indicate the 5 th and 95 th percentiles, respectively.

weak and strong snowfall rates are respectively below and above these values. ASR tends to show a lower occurrence of weak snowfall rates and a higher occurrence of strong snowfall rates compared to CloudSat. The strong snowfall rates are considered above 300 (DJF), 50 (JJA), and $150 \mathrm{~mm} \mathrm{yr}^{-1}$ (SON). In spring (MAM), ASR overestimates the occurrence of moderate snowfall rates (50$100 \mathrm{~mm} \mathrm{yr}^{-1}$ ) compared to CloudSat, while there is a good agreement for strong snowfall rates. The underestimation of weak snowfall rates takes place below 50 (DJF), 20 (MAM), 20 (JJA), and $50 \mathrm{~mm} \mathrm{yr}^{-1}$ (SON). Overall, the distributions show a good agreement between the datasets (i.e., the peaks in winter at 100 and $300 \mathrm{~mm} \mathrm{yr}^{-1}$ are found in reanalyses), attesting to a similar seasonal cycle.

The annual snowfall rates for different regions are plotted in Fig. 12. Over the whole Arctic, ERA-I underestimates snowfall rates compared to CloudSat, although this underestimation is slightly reduced over ocean. Snowfall rates from ASR (both versions) are closer to snowfall rates of CloudSat than ERA-I. For each surface type except land without Greenland, ASRv1 overestimates snowfall rates while ASRv2 underestimates it. Both are closer to CloudSat snowfall rates over continent $\left( \pm 10 \mathrm{~mm} \mathrm{yr}^{-1}\right)$ than over ocean $\left( \pm 25 \mathrm{~mm} \mathrm{yr}^{-1}\right)$. Annual variability is qualitatively similar in all products. Greenland presents a mean snowfall rate $\left(274 \mathrm{~mm} \mathrm{yr}^{-1}\right)$ higher than the rest of the Arctic $\left(183 \mathrm{~mm} \mathrm{yr}^{-1}\right)$, and also the highest differences between datasets (up to $80 \mathrm{~mm} \mathrm{yr}^{-1}$ ), which may be due to the sharply varying topography, which is difficult to take into account in a model, especially considering a coarse spatial resolution. When excluding Greenland in the land annual snowfall rates (Fig. 12, rightmost subplot), the overestimation of ASRv1 values compared to CloudSat appears slightly more pronounced, whereas ASRv2 snowfall rates become quite similar to CloudSat. Figure 13 presents seasonal snowfall rates as a function of the surface type. As seen in Fig. 11, similar seasonal cycles are produced by the reanalyses and CloudSat. From this graph, lower snowfall rates for each reanalysis compared to CloudSat can be clearly observed in spring over all surfaces. The biggest differences between datasets take place during the colder months, when snowfall rates are the highest.

\section{Discussion and conclusions}

In the context of the Arctic amplification, potential modifications of the microphysics of snowfall and snowfall patterns are expected at high latitudes. It is of the uppermost importance to better characterize snowfall rates in polar environments. Remote sensing, and especially radars like CloudSat, appears to be an optimal tool for this task. Several studies have evaluated CloudSat snowfall retrievals using ground-based radar networks over the United States (Cao et al. 2014; Chen et al. 2016) and Sweden (Norin et al. 2015), as well as over the Antarctica ice sheet (Souverijns et al. 2018; Lemonnier et al. 2019). The reliability of CloudSat for snowfall estimation in these areas supports its use in Arctic (Thomas et al. 2019). 


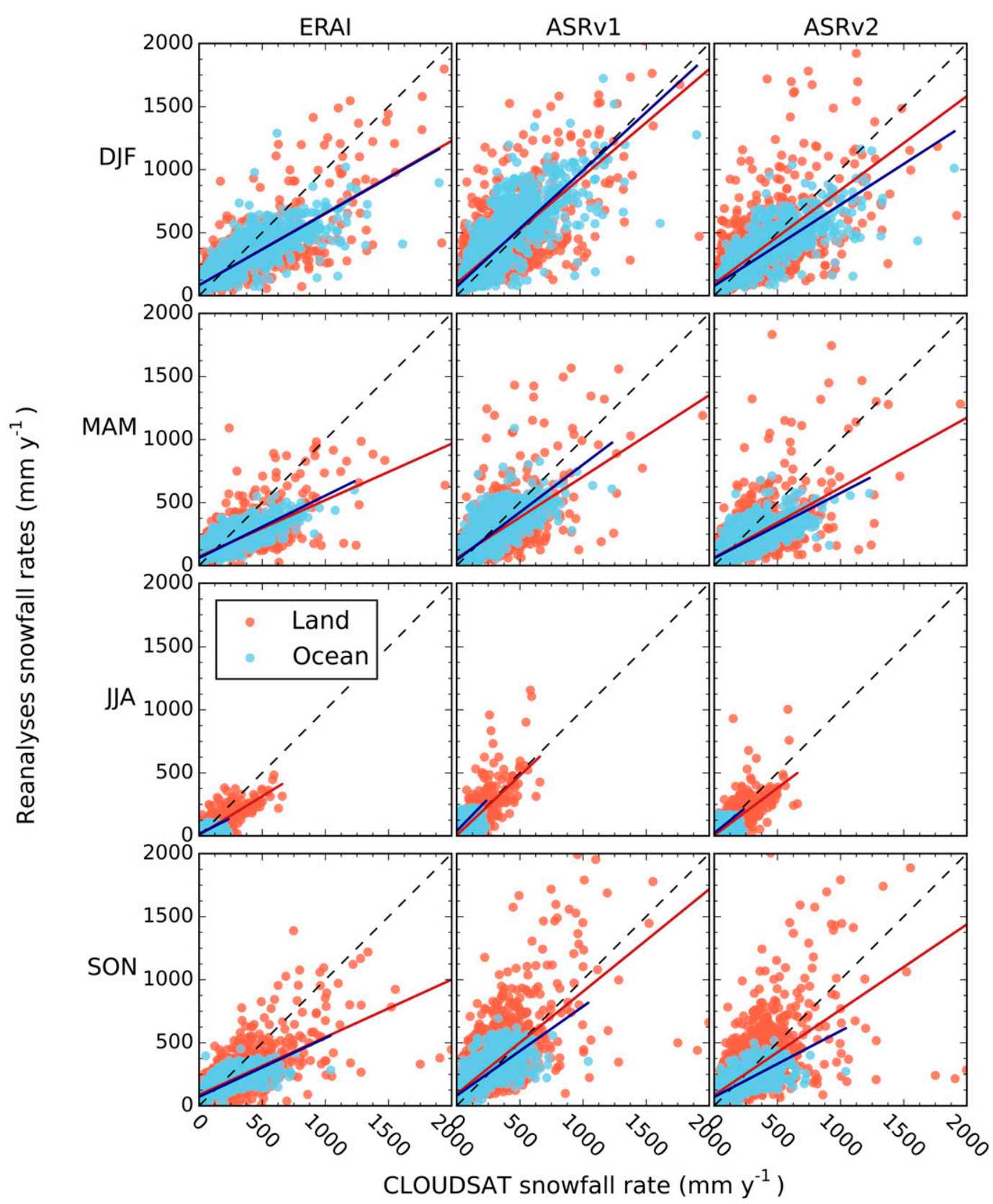

FIG. 10. Seasonal snowfall rate correlation between CloudSat and (left) ERA-I, (center) ASR version 1, and (right) ASR version 2 over 2007-10. See correlation coefficients and biases in Table 3 .

First, a 4-yr CloudSat snowfall climatology has been assembled over the Arctic region. The latter shows that frequency of solid precipitation is higher than $70 \%$ over the central Arctic Ocean, with an increasing frequency northward and over Greenland ice sheet. Frequency of mixed precipitation is around $50 \%$ mainly located in the North Atlantic, and frequency of liquid precipitation is around $40 \%$ over land south of $70^{\circ} \mathrm{N}$, while both are significant $(\sim 5 \%-15 \%)$ in the Arctic Ocean peripheral seas. Over the Greenland Ice Sheet, the Arctic Ocean, and East Siberia at least $60 \%$ of precipitation events are detected as possible, indicating light snowfall events. The CloudSat mean surface snowfall rates is around $183 \mathrm{~mm} \mathrm{yr}^{-1}$. Intense mean snowfall rates are located over Greenland, the Barents Sea, and the Alaska range $\left(>500 \mathrm{~mm} \mathrm{yr}^{-1}\right.$ ) and maxima over the southeast coast of Greenland (up to $2000 \mathrm{~mm} \mathrm{yr}^{-1}$ ). Spurious high snowfall rate spots $\left(>4000 \mathrm{~mm} \mathrm{yr}^{-1}\right)$ associated with high relative 
TABLE 3. Correlation coefficients $(r)$ and biases $\left(\mathrm{mm} \mathrm{yr}^{-1}\right)$ according to Fig. 10, and averaged between 2007 and 2010. Statistics are computed between each dataset compared to CloudSat. All correlations are statistically significant at a $99 \%$ level.

\begin{tabular}{|c|c|c|c|c|c|c|c|}
\hline & & \multicolumn{2}{|c|}{ ERA-I } & \multicolumn{2}{|c|}{ ASRv1 } & \multicolumn{2}{|c|}{ ASRv2 } \\
\hline & & Land & Ocean & Land & Ocean & Land & Ocean \\
\hline \multirow[t]{2}{*}{ DJF } & Correlation & 0.72 & 0.85 & 0.67 & 0.86 & 0.63 & 0.86 \\
\hline & Bias & -27 & -29 & 54 & 51 & 24 & -14 \\
\hline \multirow[t]{2}{*}{ MAM } & Correlation & 0.59 & 0.83 & 0.56 & 0.81 & 0.51 & 0.80 \\
\hline & Bias & -47 & -43 & -19 & -5 & -34 & -40 \\
\hline \multirow[t]{2}{*}{ JJA } & Correlation & 0.87 & 0.70 & 0.83 & 0.70 & 0.81 & 0.71 \\
\hline & Bias & -9 & 0 & 2 & 39 & -7 & 15 \\
\hline \multirow[t]{2}{*}{ SON } & Correlation & 0.63 & 0.80 & 0.62 & 0.77 & 0.56 & 0.76 \\
\hline & Bias & -44 & -46 & 47 & 16 & 5 & -34 \\
\hline \multirow[t]{2}{*}{ Average } & Correlation & 0.77 & 0.89 & 0.74 & 0.88 & 0.70 & 0.88 \\
\hline & Bias & -41 & -31 & 12 & 23 & -12 & -20 \\
\hline
\end{tabular}

uncertainties are likely linked to the high topography variability in the east and west coasts of Greenland near $70^{\circ} \mathrm{N}$. Despite the clear improvements of $2 \mathrm{C}-\mathrm{SNOW}-$ PROFILE version R05 compared to previous version,
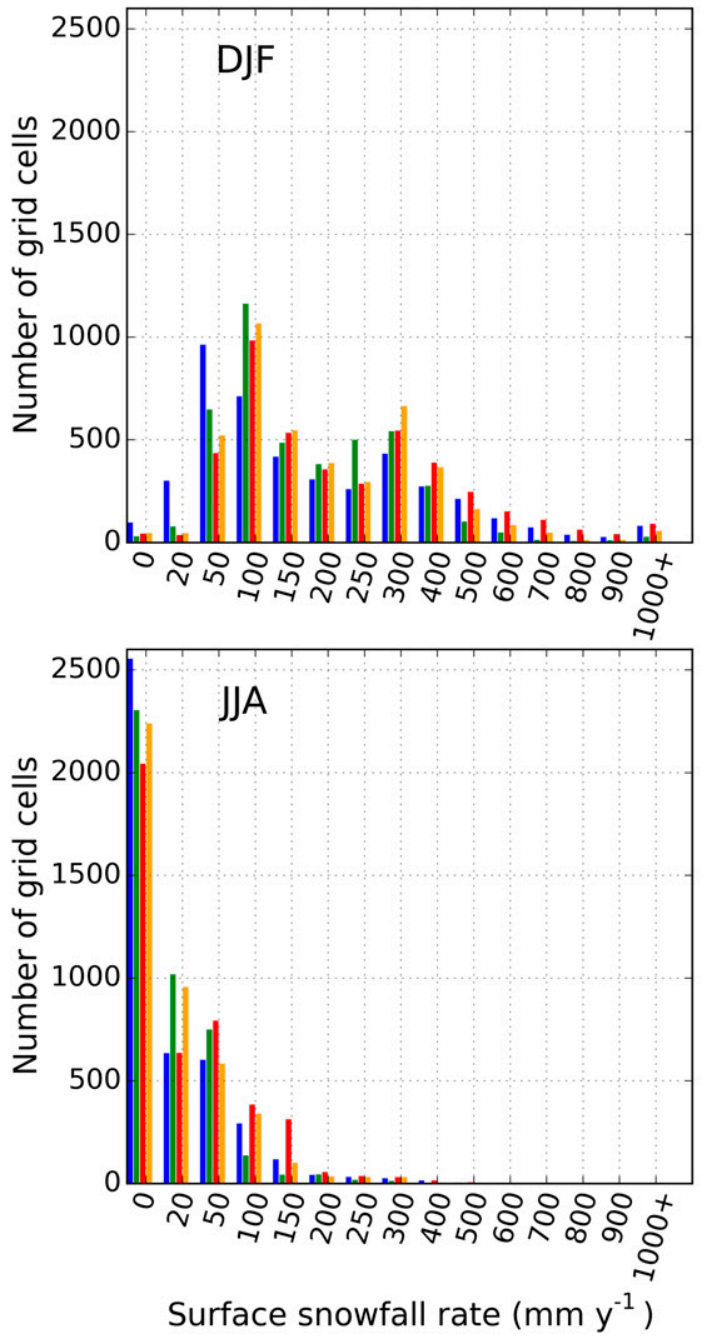

erroneous profiles remain over these specific locations. Note that profiles with a snow_retrieval_status flag value $>3$ and profiles detected as "very low confidence" have been removed. The latter especially removes the

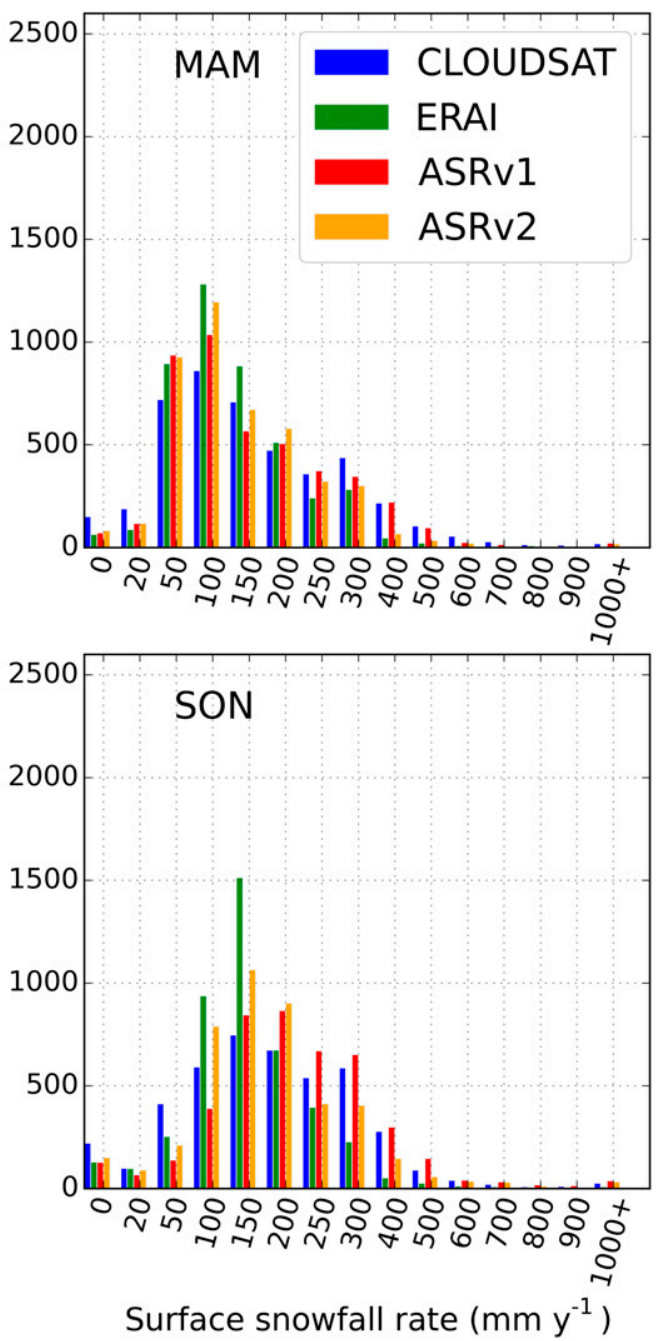

FIG. 11. Number of grid cells as a function of seasonal mean of surface snowfall rate over 2007-10 for (top left) winter, (top right) spring, (bottom left) summer, and (bottom right) autumn for CloudSat, ERA-I, ASRv1, and ASRv2. Grid cells are taken from Fig. 6. 


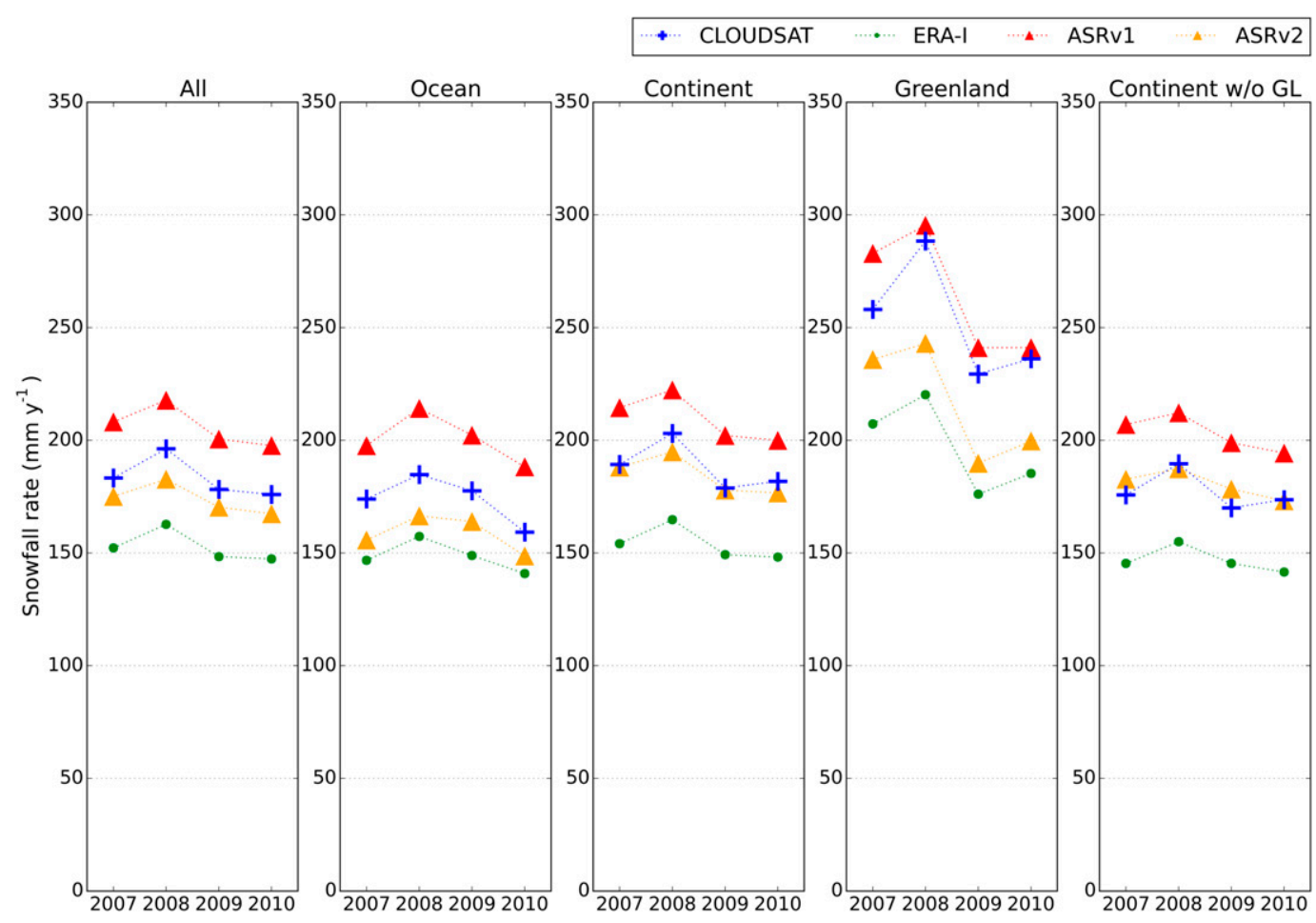

FIG. 12. Annual mean of surface snowfall rate over 2007-10 for (left to right) the whole Arctic, oceanic surfaces, continental surfaces, Greenland (GL), and continent except Greenland for CloudSat, ERA-I, ASRv1, and ASRv2.

mixed phase precipitation $(0<$ melted fraction $<0.15)$, which would increase CloudSat mean surface snowfall rates to $211 \mathrm{~mm} \mathrm{yr}^{-1}$.

Then, the CloudSat snowfall climatology has been used to evaluate a global reanalysis (ERA-I) and two versions of a regional reanalysis (Arctic System Reanalysis). All reanalyses represent qualitatively well the interannual and seasonal cycle of snowfall rates compared to CloudSat. Yet quantitative differences remain with various behaviors depending on the reanalysis and the season. Regional reanalyses (both ASR versions) show closer results with CloudSat compared to ERA-I, especially over Greenland, which is the area with the largest discrepancies. In winter, large differences between reanalyses and CloudSat are located over Siberia, the Canadian Archipelago, and Greenland, whereas they occur over the whole Arctic in summer. Generally, all products show a similar seasonal and interannual cycle. Yet, ERA-I shows an overestimation of the moderate snowfall occurrence, and an underestimation of weak and strong snowfall occurrence compared to CloudSat. While ASR shows a closer agreement to CloudSat, it tends to underestimate the weak snowfall occurrence and overestimate the strong snowfall occurrence. The snowfall rates values for weak $\left(\leq \sim 50 \mathrm{~mm} \mathrm{yr}^{-1}\right)$, moderate, and strong $\left(\geq \sim 250 \mathrm{~mm} \mathrm{yr}^{-1}\right)$ events vary seasonally. All through the year except in summer, ERA-I strongly underestimates seasonal snowfall rates over all surfaces compared to CloudSat $\left(\geq 25 \mathrm{~mm} \mathrm{yr}^{-1}\right)$. This is partially due to the low snowfall to precipitation ratio, which results in a high rainfall fraction (Dutra et al. 2011; Boisvert et al. 2018; Wang et al. 2019). In summer, ERA-I shows a better agreement over ocean with CloudSat than ASR. Annual mean snowfall rates of ASRv1 (ASRv2) display an overestimation (underestimation) over all surfaces of about $15 \mathrm{~mm} \mathrm{yr}^{-1}$ (10 $\left.\mathrm{mm} \mathrm{yr}^{-1}\right)$ compared to CloudSat. ASR snowfall rates are closer to CloudSat ones over continental areas than over ocean. In term of mean snowfall rates, ASRv2 shows the best agreement with CloudSat $\left(174 \mathrm{~mm} \mathrm{yr}^{-1}\right)$ compared to ASRv1 (206 $\left.\mathrm{mm} \mathrm{yr}^{-1}\right)$ and ERA-I $\left(153 \mathrm{~mm} \mathrm{yr}^{-1}\right)$, and its use is recommended by this study over the whole Arctic, except over Greenland. The present intercomparison attests that the new version of ASR produces significantly smaller snowfall rates $(\sim 10 \%)$ when compared to the first version, except over land in summer. This concurs with results from Bromwich et al. (2018) that showed less total precipitation during winter months in ASRv2 than in ASRv1 when compared to in situ polar stations. The distinction between solid and liquid precipitation is based on temperature for both satellite retrievals and reanalyses, and the 


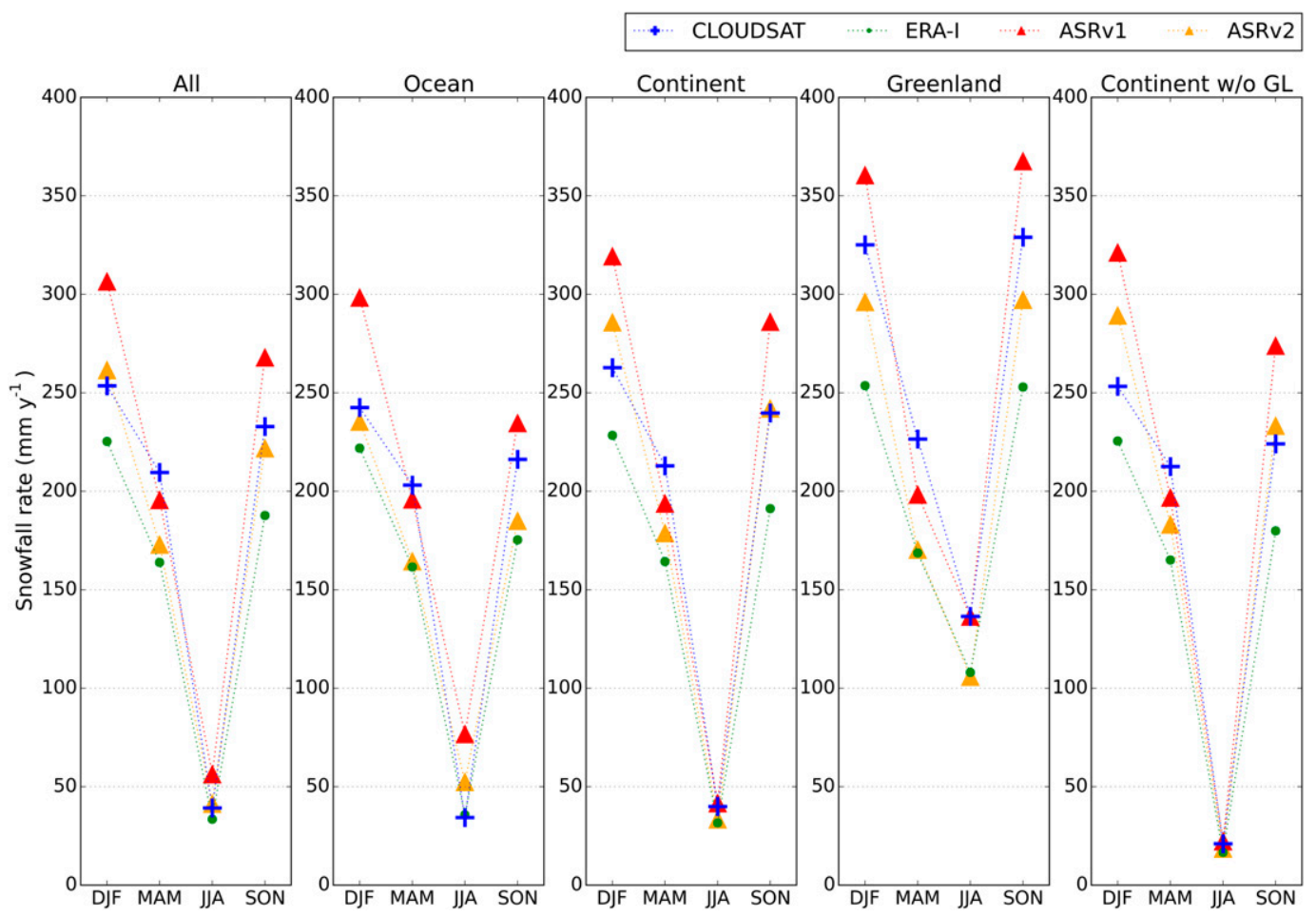

FIG. 13. As in Fig. 12, but with seasonal means.

various methods used can be a significant source of the difference between products. This is particularly true concerning ERA-I, which shows a higher rain frequency than CloudSat over the Arctic Ocean as well as North Atlantic (not shown). The rain/snowfall partition method is also pointed out by other studies (Dutra et al. 2011; Wang et al. 2019).

There are inconsistencies between the present results and those given by Boisvert et al. (2018) for ASRv1, even allowing for the area north of $82^{\circ} \mathrm{N}$ not observed by CloudSat. Figure 6 in Boisvert et al. (2018) gives 2007-10 annual snowfall amounts for ASRv1 as being smaller than ERA-I for both the central Arctic Ocean $(\sim 10 \%)$ and for all ocean areas north of $60^{\circ} \mathrm{N}(\sim 25 \%)$. Similarly, Fig. 12 in Boisvert et al. (2018) presents a comparison between buoy measurements of snow depth and those inferred from ASRv1 and ERA-I precipitation along with an illustrative comparison for a buoy in the Beaufort Sea during 2011; snow depths for ASRv1 were a few percent smaller than those for ERA-I, but both were close to the observed values. The present analysis shows ASRv1 annual snowfall exceeds that from ERA-I by about $37 \%$ for ocean areas between $58^{\circ}$ and $82^{\circ} \mathrm{N}$, which is dominated by the $\sim 30 \%$ larger amounts at lower latitudes. This difference occurs because Boisvert et al. (2018) consider only nonconvective solid precipitation for ASR (L. Boisvert 2019, personal communication). Here total snowfall (convective plus nonconvective) amounts are compared for all reanalyses.

This study presents limitations. The fully operating CloudSat period extends between June 2006 and April 2011, and restrains the study to the period between 2007 and 2010, although a longer duration would be required to assess snowfall on climatological time scales. The CloudSat orbit imposes a decreasing amount of observation equatorward and a significant part of the Arctic Ocean is missed northward of $82^{\circ} \mathrm{N}$. Due to this low spatial sampling, the more equatorward, the more precipitating events might be missed. At the same time, an important event could be sampled over a grid cell that gets several overpasses, creating a positive bias. The commission and omission errors tend to compensate for the low spatial sampling of the satellite (Souverijns et al. 2018). Northward of $82^{\circ} \mathrm{N}$, although snowfall rates are believed to be weak, precipitation is a crucial aspect in this region that produces most of the Arctic sea ice. Hence, the sampling of the nadir-looking CPR does not permit a validation at the scale of an event, yet it is adequate for a multiyear scale.

The reflectivity of the surface contaminates a significant part at the lower part of the profile that must be removed to compute snowfall rates. The four lowest bins over continents and the two lowest bins over open ocean are excluded leading to estimation errors at the surface 
and increased uncertainties. Snowfall rates are likely to change before reaching the ground due to processes such as aggregation or evaporation. A strong evaporation phenomenon has recently been observed over the coasts of Antarctica in presence of katabatic winds (Grazioli et al. 2017) and is likely to take place around Greenland at lower intensity. Over Ny-Alesund station, in the Svalbard Archipelago, 1-yr data from groundbased Micro Rain Radar and CloudSat have shown that shallow precipitation occurs more frequently than sublimation, and that CloudSat underestimates the total precipitation amount by $9 \%$ (Maahn et al. 2014). In spite of these limitations, CloudSat clearly demonstrates the usefulness of such an instrument.

For the future, it would be interesting to compare CloudSat to ERA5, since it has a better spatial resolution and a higher ratio of snowfall to precipitation over sea ice between 2010 and 2015 than ERA-Interim (Wang et al. 2019). Expanding the intercomparison period up to 2018 would bring relevant information even though it would be restricted to boreal summer because only daylight measurements are available after April 2011.

Finally ground-based precipitation datasets are also required to assess CloudSat snowfall rates. These measurements are difficult to obtain and present significant uncertainties. However, additional comparison studies must be performed with in situ data, to ensure the reliability of CloudSat products.

Acknowledgments. This study was supported by the National French Research Agency (ANR) program AC-AHC2 (Circulation Atmospheric and Hydrological Cycle Changes in Arctic) ANR-15-CE01-0003. This work was partially supported by the National Center of Spatial Studies (CNES) program EECLAT (Expecting Earth-Care, Learning from A-Train). ECMWF, National Center for Atmospheric Research (NCAR), and Polar Meteorology Group of Ohio State University (POLARMET) are acknowledged for supplying ERA-I and ASR products used in this study. Parts of this research by N. B. Wood and T. L'Ecuyer were performed at the University of Wisconsin-Madison for the Jet Propulsion Laboratory, California Institute of Technology, sponsored by the National Aeronautics and Space Administration. CloudSat data were obtained from the CloudSat Data Processing Center (http://www.cloudsat.cira.colostate.edu). D. Bromwich's participation was funded by ONR Grant N00014-18-1-2361. This is Contribution 1585 of Byrd Polar and Climate Research Center. We thank the Climserv platform for the use of their server in order to conduct this study. The authors want to sincerely thank the three anonymous reviewers for the suggestions that greatly improved the manuscript.

\section{REFERENCES}

Behrangi, A., and Coauthors, 2016: Status of high-latitude precipitation estimates from observations and reanalyses. $J$. Geophys. Res. Atmos., 121, 4468-4486, https://doi.org/10.1002/ $2015 J D 024546$.

Bintanja, R., and F. Selten, 2014: Future increases in Arctic precipitation linked to local evaporation and sea-ice retreat. Nature, 509, 479-482, https://doi.org/10.1038/nature13259.

Boisvert, L. N., M. A. Webster, A. A. Petty, T. Markus, D. H. Bromwich, and R. I. Cullather, 2018: Intercomparison of precipitation estimates over the Arctic Ocean and its peripheral seas from reanalyses. J. Climate, 31, 8441-8462, https:// doi.org/10.1175/JCLI-D-18-0125.1.

Bromwich, D. H., J. P. Nicolas, and A. J. Monaghan, 2011: An assessment of precipitation changes over Antarctica and the Southern Ocean since 1989 in contemporary global reanalyses. J. Climate, 24, 4189-4209, https://doi.org/10.1175/2011JCLI4074.1.

— L. Lai, K. Hines, S. Wang, Z. Liu, H.-C. Lin, Y. Kuo, and M. Barlage, 2012: Arctic System Reanalysis (ASR) project. Research Data Archive at the National Center for Atmospheric Research, Computational and Information Systems Laboratory, accessed 29 May 2017, https://doi.org/10.5065/D6K072B5.

— A. B. Wilson, L.-S. Bai, G. W. Moore, and P. Bauer, 2016: A comparison of the regional Arctic System Reanalysis and the global ERA-Interim reanalysis for the Arctic. Quart. J. Roy. Meteor. Soc., 142, 644-658, https://doi.org/10.1002/qj.2527.

— , and Coauthors, 2018: The Arctic System Reanalysis, version 2. Bull. Amer. Meteor. Soc., 99, 805-828, https://doi.org/ 10.1175/BAMS-D-16-0215.1.

Cao, Q., Y. Hong, S. Chen, J. J. Gourley, J. Zhang, and P. E. Kirstetter, 2014: Snowfall detectability of NASA's CloudSat: The first cross-investigation of its 2C-SNOW-PROFILE product and National Multi-Sensor Mosaic QPE (NMQ) snowfall data. Prog. Electromagn. Res., 148, 55-61, https://doi.org/10.2528/ PIER14030405.

Chen, S., and Coauthors, 2016: Comparison of snowfall estimates from the NASA CloudSat cloud profiling radar and NOAA/ NSSL multi-radar multi-sensor system. J. Hydrol., 541, 862872, https://doi.org/10.1016/j.jhydrol.2016.07.047.

Dee, D. P., and Coauthors, 2011: The ERA-Interim Reanalysis: Configuration and performance of the data assimilation system. Quart. J. Roy. Meteor. Soc., 137, 553-597, https://doi.org/ 10.1002/qj.828.

Dutra, E., S. Kotlarski, P. Viterbo, G. Balsamo, P. M. Miranda, C. Schär, P. Bissolli, and T. Jonas, 2011: Snow cover sensitivity to horizontal resolution, parameterizations, and atmospheric forcing in a land surface model. J. Geophys. Res., 116, D21109 https://doi.org/10.1029/2011JD016061.

Francis, J. A., D. M. White, J. J. Cassano, W. J. Gutowski, L. D. Hinzman, M. M. Holland, M. A. Steele, and C. J. Vörösmarty, 2009: An Arctic hydrologic system in transition: Feedbacks and impacts on terrestrial, marine, and human life. J. Geophys. Res., 114, G04019, https://doi.org/10.1029/2008JG000902.

Grazioli, J., J.-B. Madeleine, H. Gallée, R. M. Forbes, C. Genthon, G. Krinner, and A. Berne, 2017: Katabatic winds diminish precipitation contribution to the Antarctic ice mass balance. Proc. Natl. Acad. Sci. USA, 114, 10 858-10 863, https://doi.org/ 10.1073/pnas.1707633114.

Haynes, J. M., T. S. L'Ecuyer, G. L. Stephens, S. D. Miller, C. Mitrescu, N. B. Wood, and S. Tanelli, 2009: Rainfall retrieval over the ocean with spaceborne W-band radar. J. Geophys. Res., 114, D00A22, https://doi.org/10.1029/2008JD009973. 
Kain, J. S., 2004: The Kain-Fritsch convective parameterization: An update. J. Appl. Meteor., 43, 170-181, https://doi.org/ 10.1175/1520-0450(2004)043<0170:TKCPAU>2.0.CO;2.

—, and J. M. Fritsch, 1990: A one-dimensional entraining/ detraining plume model and its application in convective parameterization. J. Atmos. Sci., 47, 2784-2802, https://doi.org/ 10.1175/1520-0469(1990)047<2784:AODEPM>2.0.CO;2.

Kulie, M. S., and L. Milani, 2018: Seasonal variability of shallow cumuliform snowfall: A CloudSat perspective. Quart. J. Roy. Meteor. Soc., 144, 329-343, https://doi.org/10.1002/qj.3222.

,-- N. B. Wood, S. A. Tushaus, R. Bennartz, and T. S. L'Ecuyer, 2016: A shallow cumuliform snowfall census using spaceborne radar. J. Hydrometeor., 17, 1261-1279, https:// doi.org/10.1175/JHM-D-15-0123.1.

Lemonnier, F., and Coauthors, 2019: Evaluation of CloudSat snowfall rate profiles by a comparison with in situ micro-rain radar observations in East Antarctica. Cryosphere, 13, 943954, https://doi.org/10.5194/tc-13-943-2019.

Levizzani, V., S. Laviola, and E. Cattani, 2011: Detection and measurement of snowfall from space. Remote Sens., 3, 145166, https://doi.org/10.3390/rs3010145.

Liu, G., 2008: Deriving snow cloud characteristics from CloudSat observations. J. Geophys. Res., 113, D00A09, https://doi.org/ 10.1029/2007JD009766.

Liu, Y., J. R. Key, Z. Liu, X. Wang, and S. J. Vavrus, 2012: A cloudier Arctic expected with diminishing sea ice. Geophys. Res. Lett., 39, L05705, https://doi.org/10.1029/2012GL051251.

Maahn, M., C. Burgard, S. Crewell, I. V. Gorodetskaya, S. Kneifel, S. Lhermitte, K. Van Tricht, and N. P. van Lipzig, 2014: How does the spaceborne radar blind zone affect derived surface snowfall statistics in polar regions? J. Geophys. Res. Atmos., 119, 13 604-13 620, https://doi.org/10.1002/2014JD022079.

Merkouriadi, I., B. Cheng, R. M. Graham, A. Rösel, and M. A. Granskog, 2017: Critical role of snow on sea ice growth in the Atlantic sector of the Arctic Ocean. Geophys. Res. Lett., 44, 10 479-10 485, https://doi.org/10.1002/2017GL075494.

Milani, L., and Coauthors, 2018: CloudSat snowfall estimates over Antarctica and the Southern Ocean: An assessment of independent retrieval methodologies and multi-year snowfall analysis. Atmos. Res., 213, 121-135, https://doi.org/10.1016/ j.atmosres.2018.05.015.

Mitrescu, C., T. L'Ecuyer, J. Haynes, S. Miller, and J. Turk, 2010: CloudSat precipitation profiling algorithm-Model description. J. Appl. Meteor. Climatol., 49, 991-1003, https://doi.org/ 10.1175/2009JAMC2181.1.

NCAR, 2017: Arctic System Reanalysis version 2. Research Data Archive at the National Center for Atmospheric Research, Computational and Information Systems Laboratory, accessed 29 May 2017, https://doi.org/10.5065/D6X9291B.

Nitu, R., and Coauthors, 2018: WMO Solid Precipitation Intercomparison Experiment (SPICE) (2012-2015). IOM Rep. 131, 1445 pp., https://library.wmo.int/index.php? lvl=notice_display\&id $=20742$.

Norin, L., A. Devasthale, T. L'Ecuyer, N. Wood, and M. Smalley, 2015: Intercomparison of snowfall estimates derived from the CloudSat Cloud Profiling Radar and the ground-based weather radar network over Sweden. Atmos. Meas. Tech., 8 , 5009-5021, https://doi.org/10.5194/amt-8-5009-2015.

Palerme, C., J. Kay, C. Genthon, T. L'Ecuyer, N. Wood, and C. Claud, 2014: How much snow falls on the Antarctic ice sheet? Cryosphere, 8, 1577-1587, https://doi.org/10.5194/tc-8-1577-2014. , C. Claud, A. Dufour, C. Genthon, N. B. Wood, and T. L'Ecuyer, 2017: Evaluation of Antarctic snowfall in global meteorological reanalyses. Atmos. Res., 190, 104-112, https:// doi.org/10.1016/j.atmosres.2017.02.015.

,,-- N. Wood, T. L'Ecuyer, and C. Genthon, 2019: How does ground clutter affect CloudSat snowfall retrievals over ice sheets? IEEE Geosci. Remote Sens. Lett., 16, 342-346, https://doi.org/10.1109/LGRS.2018.2875007.

Rawlins, M. A., and Coauthors, 2010: Analysis of the Arctic system for freshwater cycle intensification: Observations and expectations. J. Climate, 23, 5715-5737, https://doi.org/10.1175/ 2010JCLI3421.1.

Sassen, K., and Z. Wang, 2008: Classifying clouds around the globe with the CloudSat radar: 1-year of results. Geophys. Res. Lett., 35, L04805, https://doi.org/10.1029/2007GL032591.

Screen, J. A., and I. Simmonds, 2012: Declining summer snowfall in the Arctic: Causes, impacts and feedbacks. Climate Dyn., 38, 2243-2256, https://doi.org/10.1007/s00382-011-1105-2.

Serreze, M. C., and R. G. Barry, 2011: Processes and impacts of arctic amplification: A research synthesis. Global Planet. Change, 77, 85-96, https://doi.org/10.1016/j.gloplacha.2011.03.004.

Souverijns, N., and Coauthors, 2018: Evaluation of the CloudSat surface snowfall product over Antarctica using ground-based precipitation radars. Cryosphere, 12, 3775-3789, https://doi.org/ 10.5194/tc-12-3775-2018

Surussavadee, C., and D. H. Staelin, 2009: Satellite retrievals of Arctic and equatorial rain and snowfall rates using millimeter wavelengths. IEEE Trans. Geosci. Remote Sens., 47, 36973707, https://doi.org/10.1109/TGRS.2009.2029093.

Tao, W.-K., 2003: Goddard Cumulus Ensemble (GCE) model: Application for understanding precipitation processes. Cloud Systems, Hurricanes, and the Tropical Rainfall Measuring Mission (TRMM): A Tribute to Joanne Simpson, W.-K. Tao and R. Adler, Eds., Springer, 107-138.

, and J. Simpson, 1993: The Goddard Cumulus Ensemble model. Part I: Model description. Terr. Atmos. Oceanic Sci., 4, 35-72, https://doi.org/10.3319/TAO.1993.4.1.35(A).

— , and Coauthors, 2014: The Goddard Cumulus Ensemble model (GCE): Improvements and applications for studying precipitation processes. Atmos. Res., 143, 392-424, https:// doi.org/10.1016/j.atmosres.2014.03.005.

Thomas, M. A., A. Devasthale, T. L'Ecuyer, S. Wang, T. Koenigk, and K. Wyser, 2019: Snowfall distribution and its response to the Arctic Oscillation: An evaluation of HighResMIP models in the Arctic using CPR/CloudSat observations. Geosci. Model Dev., 12, 3759-3772, https://doi.org/10.5194/gmd-12-3759-2019.

Tiedtke, M., 1993: Representation of clouds in large-scale models. Mon. Wea. Rev., 121, 3040-3061, https://doi.org/10.1175/15200493(1993)121<3040:ROCILS > 2.0.CO;2.

Wang, C., R. M. Graham, K. Wang, S. Gerland, and M. A. Granskog, 2019: Comparison of ERA5 and ERA-Interim near-surface air temperature, snowfall and precipitation over Arctic sea ice: Effects on sea ice thermodynamics and evolution. Cryosphere, 13, 1661-1679, https://doi.org/10.5194/tc-131661-2019.

Wood, N. B., and T. S. L'Ecuyer, 2018: Level 2c snow profile process description and interface control document, product version p1 r05. NASA JPL CloudSat project document revision 0, 26 pp., http://www.cloudsat.cira.colostate.edu/dataproducts/level-2c/2c-snow-profile?term $=90$.

, — - A. J. Heymsfield, G. L. Stephens, D. R. Hudak, and P. Rodriguez, 2014: Estimating snow microphysical properties using collocated multisensor observations. $J$. Geophys. Res. Atmos., 119, 8941-8961, https://doi.org/10.1002/ 2013JD021303. 